\title{
Plasma Corticosterone Levels in the Male Iguanid Lizard, Sceloporus cyanogenys, Under Various Physiological Conditions
}

David Reams Daugherty

College of William \& Mary - Arts \& Sciences

Follow this and additional works at: https://scholarworks.wm.edu/etd

Part of the Physiology Commons

\section{Recommended Citation}

Daugherty, David Reams, "Plasma Corticosterone Levels in the Male Iguanid Lizard, Sceloporus cyanogenys, Under Various Physiological Conditions" (1971). Dissertations, Theses, and Masters Projects. Paper 1539624722.

https://dx.doi.org/doi:10.21220/s2-jk2d-cq40

This Thesis is brought to you for free and open access by the Theses, Dissertations, \& Master Projects at W\&M ScholarWorks. It has been accepted for inclusion in Dissertations, Theses, and Masters Projects by an authorized administrator of W\&M ScholarWorks. For more information, please contact scholarworks@wm.edu. 
PLASMA CORTICOSTERONE LEVELS

IN THE MALE IGUANID LIZARD, SCELOPORUS CYANOGENYS, UNDER VARIOUS PHYSIOLOGICAL CONDITIONS

A Thesis

Presented to

The Faculty of the Department of Biology

The College of William and Mary in Virginia

In Partial Fulfillment

Of the Requirements for the Degree of

Master of Arts

By

David Reams Daugherty

1971 

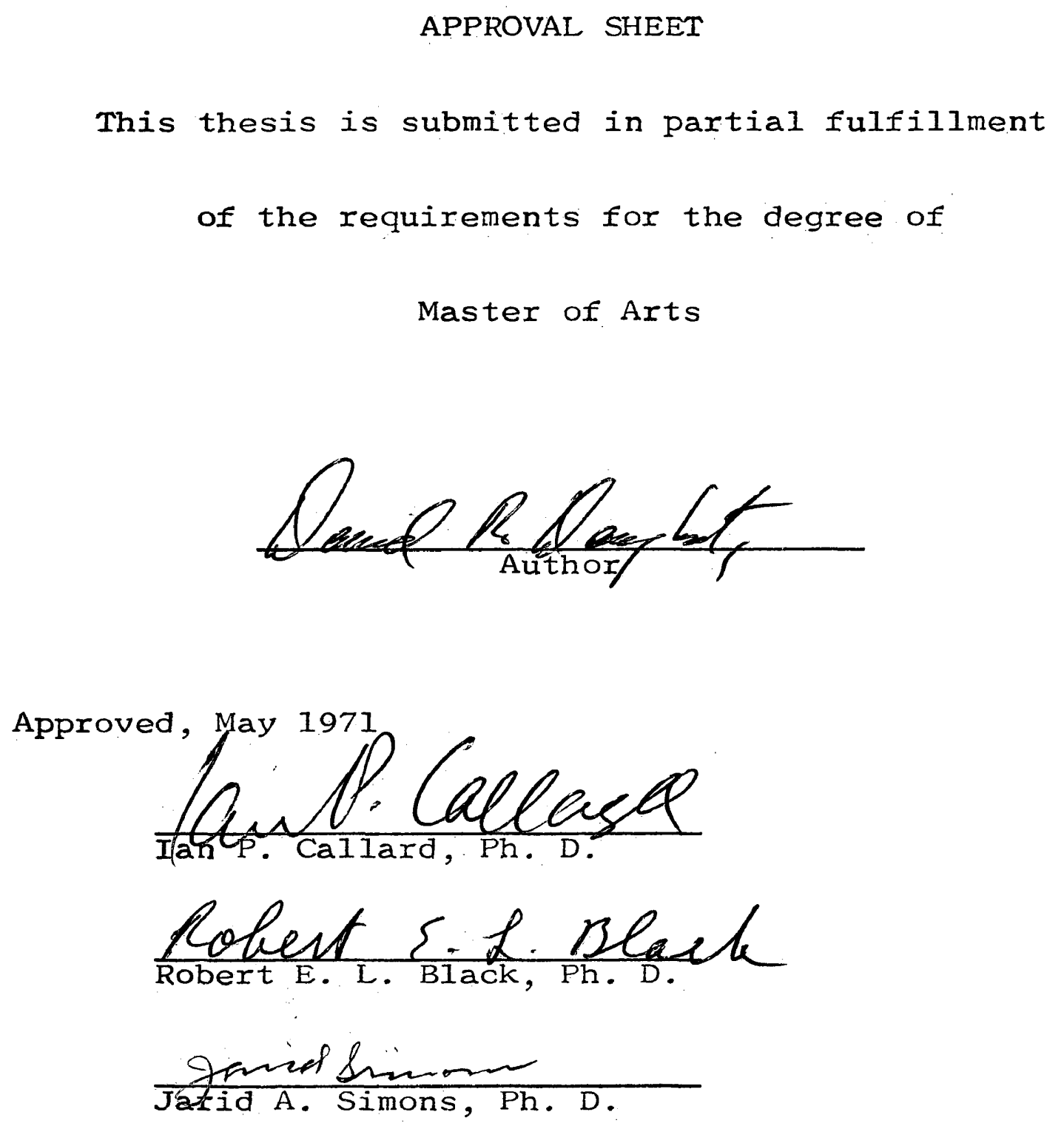


\section{ACKNOWLEDGMENTS}

The writer wishes to express his appreciation to Professor Ian P. Callard, under whose direction this investigation was conducted, for his preparation of the hypophysectomized and lesioned groups, and for his patient guidance and criticism throughout the investigation. The author is also indebted to Professor Robert E. L. Black and Professor Jarid A. Simons for their careful reading and well-received critiques of the manuscript. Thanks are also due Mrs. Theodore O. Gerstle who prepared several of the study groups. A special note of gratitude is extended to Dr. Stephen W. C. Chan for his provacative discussions, scholarly advice, and invaluable assistance. 
TABLE OF CONTENTS

Page

ACKNOWLEDGMENTS . . . . . . . . . . . . . . . . . . .

LIST OF TABLES • • • • • • • • • • • • • • • • • v

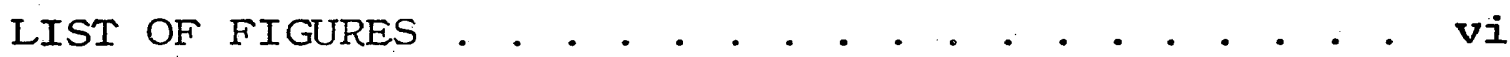

ABSTRACT •. . . . . . . . . . . . . . . . . . vii

INTRODUCTION

METHODS AND MATERIALS . . . . . . . . . . . . . . . 4

RESULTS . . • • . . . . . . . . . . . . 16

TABLES . . . . . . . . . . . . . . . 19-24

FIGURES . • . . . . . . . . . . . . . . 25-30

DISCUSSION

BIBLIOGRAPHY . . . . . . . . . . . . . . . . . . . 42 


\section{LIST OF TABLES}

Table

Page

I. Seasonal variations in plasma

corticosterone levels . . . . . . 19

II. Time-course effect of exogenous ACTH

(Animals intact)... . . . . . . 20

III. Time-course effect of exogenous ACTH

(Animals hypophysectomized) . . . . 21

IV. Effect of median eminence and anterior hypothalamic lesions on plasma corticosterone concentration . . . . 22

V. Effect of inhibitors on plasma corticosterone concentration . . . . 23

VI. Effect of estrogen and castration on plasma corticosterone concentration . . . 24 


\section{LIST OF FIGURES}

Figure

Page

I. The molecular configuration of aminoglutethimide, cyano-ketone, and metyrapone, inhibitors of adrenal steroidogenesis . . . . . . . . . 25

II. The standard curve . . . . . . . . . . . 26

III. Changes in plasma corticosterone levels following ACTH injection . . . . . . 27

IV. The effect of median eminence and anterior hypothalamic lesions on plasma corticosterone concentration . . . . . 28

V. The effect of inhibitors of adrenal corticosteroidogenesis on plasma corticosterone concentration . . . . . 29

VI. The effect of estrogen and castration on plasma corticosterone concentration . . 30 


\begin{abstract}
Variations in peripheral plasma corticosterone levels in male iguanid lizards, Sceloporus cyanogenys; were investigated under varying physiological conditions. Control baseline levels of the steroid in plasma were significantly decreased by hypophysectomy, adrenalectomy, hypothalamic lesions, and cyano-ketone, an inhibitor of $\Delta^{5}-3 \beta$ hydroxysteroid dehydrogenase. Levels were increased following treatment with mammalian ACTH in both intact and hypophysectomized lizards. In the intact animal, ACTH produced a more rapid, more prolonged, and quantitatively greater response of the adrenal gland than the same hormone when administered to the hypophysectomized animal. An apparent increase in corticosterone levels was observed following metyrapone (an $11 \beta$ hydroxylase inhibitor) treatment and aminoglutethimide, an inhibitor of the formation of pregnenolone from cholesterol, had no effect. Estrogen treatment elevated corticosterone concentration but failed to produce the same effect in the castrated animal. Castration itself had little effect.
\end{abstract}


PLASMA CORTICOSTERONE LEVELS

IN THE MALE LGUANID LIZARD, SCELOPORUS CYANOGENYS, UNDER VARIOUS PHYSIOLOGICAL CONDITIONS 


\section{INTRODUCTION}

In spite of our rapidly expanding understanding of adrenal function and control in higher vertebrates, the control of the adrenal gland and its secretion in reptiles continues to be a poorly elucidated area. Only recently has sufficient evidence been presented to indicate that the reptilian hypothalamic-adenohypophyseal-adrenocortical axis may be similar to that of higher tetrapods (Jørgensen, 1969; Callard and Chester-Jones, 1971; Phillips and Chester-Jones, 1957). Callard and Willard (1969) reported the blocking of metyrapone-induced adrenal hypertrophy by intrahypothalamic betamethazone implants in Sceloporus cyanogenys. More recently, Callard and Chester-Jones (1971) have corroborated these findings by showing that lesions in the anteromedial hypothalamus and median eminence regions have an effect similar to that of the betamethazone implants.

Studies of the influence of mammalian ACTH (Wright and Chester-Jones, 1957; Huang et al., 1969) and injections of reptilian pituitary extracts (Gist and de Roos, 1966) have indicated a role for pituitary ACTH in the control of adrenal secretion and in vitro biosynthesis of corticoids in reptiles as in mammals. More recently, Licht and Brad- 
shaw (1969) have localized the source of corticotropin to the rostral pars distalis in Anolis carolinensis and have measured peripheral levels of corticosterone, the major glucocorticoid of reptiles (Chester-Jones, et al., 1959; Gottfried, et al., 1967; Huang, et al., 1969).

The development of a highly sensitive means of estimating corticoid levels (Murphy, 1967) and its validation for use in reptiles (Bradshaw and Fontaine-Bertrand, 1969) have made it possible to use circulating corticosteroid concentrations as an index of pituitary ACTH output in reptiles.

Earlier studies from this laboratory, which used adrenal weight as the primary index of ACTH secretion, provided preliminary evidence for the existence of a hypothalamo-adenohypophyseal-adrenal axis in reptiles. By employing the competitive protein-binding radioassay for corticoids, the present investigation is an attempt to reinforce the idea of phylogenetic constancy in adrenal control. 
METHODS AND MATERIALS

I. Animals

Adult male Sceloporus cyanogenys, the blue spiny lizard, were obtained from a commercial supplier in Texas between November and April. The animals were kept in circular corrugated metal enclosures (20 $\mathrm{ft}^{2}$ area) on a bedding of "Sanicel" (Paxton Processing Co.). Room temperature varied between $80^{\circ} \mathrm{F}$ during the day and $65^{\circ} \mathrm{F}$ at night. Suspended three feet over each pen was a 250-watt heat lamp which developed a temperature gradient in the pen ranging up to $98^{\circ} \mathrm{F}$ directly under the lamp. Shade was available in each pen. The room lighting and heat lamps were maintained on a 12 hour light - 12 hour dark cycle. The animals were fed crickets daily and water was continuously available. At the outset of each experiment, each animal was weighed and identified by toe-clip. The animals for the lesion studies and metyrapone injection groups were housed in individual wire screen cages $(30 \times 30 \times 60 \mathrm{~cm})$ with up to ten animals per cage. Environmental conditions were identical to the large pens. All other study groups were maintained in individual $20 \mathrm{ft}^{2}$ enclosures. 
II. EXPERIMENTAL GROUPS

Series A- Bilateral adrenalectomy

Series B- The effect of a single injection of ACTH in intact and hypophysectomized animals autopsied at 15, 30, 60, and 90 minutes after injection

Series C- The effect of hypothalamic lesions

1. Untreated, free-running controls maintained in $20 \mathrm{ft}^{2}$ pens

2. Sham-lesioned animals (no current passed)

3. Lesioned animals

Series D- The effect of inhibitors of adrenal steroidogenesis

1. Untreated controls

2. Aminoglutethimide treated animals

3. Cyano-ketone treated animals

4. Metyrapone treated animals

Series E- The effect of castration and estrogen injection

1. Untreated controls

2. Estrogen treated animals

3. Castrated animals

4. Castrated animals treated with estrogen

III. SURGICAL PROCEDURES

A. Anesthesia

For each surgical procedure, animals were anesthetized with sodium pentobarbital (Nembutal; $2.0 \mathrm{mg} / 100 \mathrm{~g}$ body 
weight) and hypothermia.

B. Adrenalectomy

Adrenalectomy was accomplished through bilateral incisions of approximately 10-12 mm along the medial boundary of the distinctive blue sex coloration on the ventral surface immediately posterior to the last rib. The adrenal was brought to the body surface along with the testis and destroyed by electrocautery. Careful attention was paid so that the testicular blood supply and the venae cavae were not ruptured. However, because of the proximity of the adrenal to these vessels, some blood flow was usually interrupted. The wound was closed with 4-O silk sutures.

C. Castration

Castration was performed in a manner similar to adrenalectomy, the gonadal mesentery and connecting blood vessels being severed by electrocautery.

D. Hypophysectomy

Hypophysectomy was done according to Callard and ChesterJones (1971) by exposure of the pituitary through the basisphenoid bone. The gland was carefully removed with aspiration and the wound closed with Gelfoam (Upjohn Co.). Sham operations differed only in that the pituitary was exposed but not removed.

E. Lesions

Lesions were performed in a Kopf small mammal stereotaxic instrument using a Grass Model LM4 radiofrequency 
lesion maker (Callard and Chester-Jones, 1971). A drill hole was made $0.5 \mathrm{~mm}$ posterior to the center of the pineal eye. With the electrode (a stainless steel insect pin insulated with polyethylene tubing and Insulex) placed $0.5 \mathrm{~mm}$ from the bottom of the skull, single lesions were produced by passing a $23 \mathrm{~mA}$ current for 20 seconds. The electrode was then removed and the hole in the skull was closed with Gelfoam and covered with dental cement.

\section{INJECTIONS}

A total of $65 \mathrm{mg}$ metyrapone $\neq \mathrm{Su} 4885$, methyl-2 bis (3-pyridyI)-1,2-propanone-1 (CIBA) ₹ was injected subcutaneously over a period of seven days following the surgical procedure indicated. Aminoglutethimide $(2.5 \mathrm{mg} / 100 \mathrm{~g}$ body weight/day in $0.1 \mathrm{ml}$ distilled water) was injected subcutaneously daily for eight days. Cyano-ketone fWin 19,578;

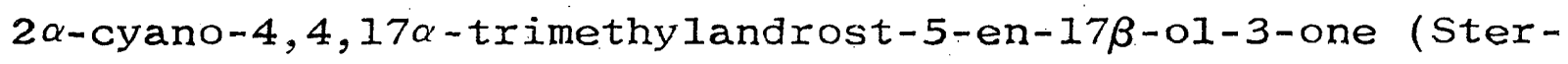
ling-Winthrop) $\neq$ was injected in $0.1 \mathrm{~m} I$ water subcutaneously daily over a seven day period in doses of $2 \mathrm{mg} / \mathrm{animal} / \mathrm{day}$. (For molecular configurations of above, see Figure I.) ACTH (porcine; 92.7 IU/mg; Sigma Chemical Co.) was injected intraperitoneally at a dose of $2 \mathrm{IU}$ in $0.1 \mathrm{ml}$ distilled water. Estradiol-17 $\beta$ was administered by subcutaneous injection in doses of $1.6 \mathrm{ug}$ in $0.1 \mathrm{ml}$ sesame oil daily for ten days.

The metyrapone and aminoglutethimide were generously 
supplied by Dr. Robert Gaunt of CIBA. Dr. Gordon Potts of Sterling-Winthrop was kind enough to furnish the cyanoketone.

$\underline{\text { V. AUTOPSY }}$

The animals were killed by decapitation and the effluent blood from each animal was collected in a heparinized tube and centrifuged at 2 , 000 rpm for 20 minutes. The plasma was drawn off and stored in small tubes at $-23^{\circ} \mathrm{C}$ until assayed. The livers, adrenals, and gonads of each animal were removed and weighed. Whole heads from the lesioned and hypophysectomized groups were fixed in 10\% formol. Lesions of the brain were located in frozen ( $80 u$ ) thionin stained sections, and the completeness of the hypophysectomy verified by examination of the sella turcica under a dissecting microscope.

VI. ESTIMATION OF PLASMA CORTICOSTERONE

Plasma corticosterone concentrations were measured in O.I ml samples using the competitive protein-binding technique of Murphy (1967) in which $\mathrm{H}^{3}$-corticosterone is quantitatively displaced from the binding protein by the unlabelled corticosterone of the unknown sample. The unbound steroid is removed by silicate adsorption and the remaining level of bound $\mathrm{H}^{3}$-corticosterone is then determined. Bradshaw and Fontaine-Bertrand (1969), who validated the use of this procedure for estimating corticosterone in birds and lizards, 
showed this method to have a maxịmum sensitivity of $0.2 \mathrm{ng}$ corticosterone with $99 \%$ confidence. When using $0.1 \mathrm{ml}$ plasma samples, values as low as $0.2 \mathrm{ug} / 100 \mathrm{ml}$ plasma could be differentiated from zero with confidence.

Whole heparinized male dog blood was centrifuged at 2,000 rpm for 20 minutes. The plasma was drawn off and stored in $1.25 \mathrm{ml}$ aliquots at $-23^{\circ} \mathrm{C}$. On demand, the plasma was thawed and diluted to $50 \mathrm{ml}$ with distilled water making a $2.5 \%$ plasma solution.

For each set of determinations, six standards and up to 70 samples were run in duplicate. A sample of $0.1 \mathrm{ml} 10 \%$ male rat plasma was included with each set of twenty samples and standards as a check on reproducibility. The entire procedure used was as follows:

A. Dialysis of the diluted dog plasma to improve sensitivity and day to day precision-

1. The diluted dog plasma was transferred to a dialysis bag and was placed in five volumes of Ringer's solution at $40^{\circ} \mathrm{C}$ for six hours.

2. The plasma solution was then transferred to an Erlenmeyer flask and 14,000-15,000 counts per minute $\mathrm{H}^{3}$-corticosterone per $\mathrm{ml}$ plasma solution were added with gentle agitation of the solution to prevent precipitation of the protein.

B. Extraction of the unknown and controls-

1. Aliquots of $0.1 \mathrm{ml}$ of lizard plasma were pipetted 
with an Eppendorf microliter pipet into $125 \times 15 \mathrm{~mm}$ test tubes in duplicate. Appropriately smaller volumes were used when corticosterone levels beyond the useful range of the standard curve were expected. 2. The plasma was extracted with 20 volumes of redistilled methylene chloride by shaking lots of twenty tubes in a test tube rack on a vortex mixer for five minutes.

3. After being shaken, the tubes were centrifuged for five minutes at $2,000 \mathrm{rpm}$ and the aqueous phase was carefully aspirated off. The methylene chloride was poured into $75 \times 12 \mathrm{~mm}$ test tubes and evaporated to dryness under a stream of air in a $41^{\circ} \mathrm{C}$ dri-bath. C. Preparation of the standards-

The working standard solutions of non-radioactive corticosterone in concentrations of $0.01 \mathrm{ug} / \mathrm{mI}$ and $0.1 \mathrm{ug} / \mathrm{mI}$ were maintained in absolute ethanol at $-23^{\circ} \mathrm{C}$. These were made up fresh each month from a stock standard of $10 \mathrm{ug} / \mathrm{ml}$ and dispensed with an Eppendorf microliter pipet in appropriate quantities for the daily standards. D. The binding reaction-

The binding reaction was carried out in the $75 \times 12 \mathrm{~mm}$ tubes in metal racks of 20 tubes. Duplicates of any sample or standard were placed in separate racks. A rat plasma control was included in each rack. The binding reaction was done as follows. 
1. $1.0 \mathrm{ml}$ of binding globulin solution prepared in A above was added to each plasma extract or standard tube and the rack was gently agitated to facilitate solution of the steroid. The rack was placed in a $45^{\circ} \mathrm{C}$ water bath for five minutes to further promote solution of the steroid.

2. The rack was removed from the water bath, shaken, and placed in an ice bath (less than $5^{\circ} \mathrm{C}$ ) for ten minutes. (Cooling the solution increases the extent of binding of the steroid to the binding globulin.)

3. Florisil ( $40 \mathrm{mg}$ ) was added to each tube and the entire rack was shaken vigorously on the vortex mixer for exactly two minutes and then replaced in the ice bath for another ten minutes. 4. With an Eppendorf microliter pipet, $0.5 \mathrm{ml}$ of the supernatant liquid from each tube was drawn off and placed in a glass scintillation vial, the Florisil having settled to the bottom of the tubes. 5. Ten ml Bray's solution (Bray, 1960) was added to each vial which was then placed in a Nuclear Chicago Series 720 liquid scintillation counter for a ten minute counting period.

E. The standard curve- (Figure II)

The standard curve was plotted as counts per minute versus nanograms of corticosterone. Unknown values were read directly from the curve. 
Radioactive corticosterone (corticosterone-1,2- $\mathrm{H}^{3}$, specific activity of $44 \mathrm{Ci} / \mathrm{mM}$ ) was obtained from the New England Nuclear Corporation of Boston, Mass. Non-radioactive corticosterone was obtained from Mann Research Laboratories, New York. The steroids were diluted or dissolved in absolute ethanol and stored at $-23^{\circ} \mathrm{C}$ without repurification.

Florisil, 60/100 mesh, was obtained from the Floridin Company of Tallahassee, Fla. The silicate was washed 12-15 times with the excess water being decanted each time. It was then dried at $110^{\circ} \mathrm{C}$ and stored at $60^{\circ} \mathrm{C}$. Each new batch was routinely checked to ascertain its ability to remove $\mathrm{H}^{3}$-corticosterone from water. Removal of more than $95 \%$ was considered acceptable. The Florisil was dispensed into each sample tube with a small spoon capable of delivering $40 \mathrm{mg}$ with good precision.

VII. CHOICE OF EXTRACTING SOLVENT FOR CORTICOSTERONE Ethanol was compared with methylene chloride and chloroform:methylene chloride $(1: 2, v: v)$. The amount of added $\mathrm{H}^{3}$-corticosterone extracted from lizard plasma by these solvents was as follows:

$\begin{array}{lccc}\text { Solvent - } & \text { EtOH } & \mathrm{MeCl}_{2} & \mathrm{CHCl}_{3}: \mathrm{MeCl}_{2} \\ \begin{array}{l}\text { Percentage } \\ \text { extraction- }\end{array} & 74.6 \pm 3.7 & 89.7 \pm 1.4 & 68.1 \pm 2.3 \\ \text { n- } & 12 & 31 & 6\end{array}$

Chloroform:methylene chloride appeared to have no peculiar 
advantages to warrant its further consideration.

The quantities of extractable corticosterone using either ethanol or methylene chloride (20 vols.) were then compared to similar samples following thin layer chromatography (TLC) using a single pool of lizard plasma with five replicates for each method. The method used and results obtained are incicated in the following table.

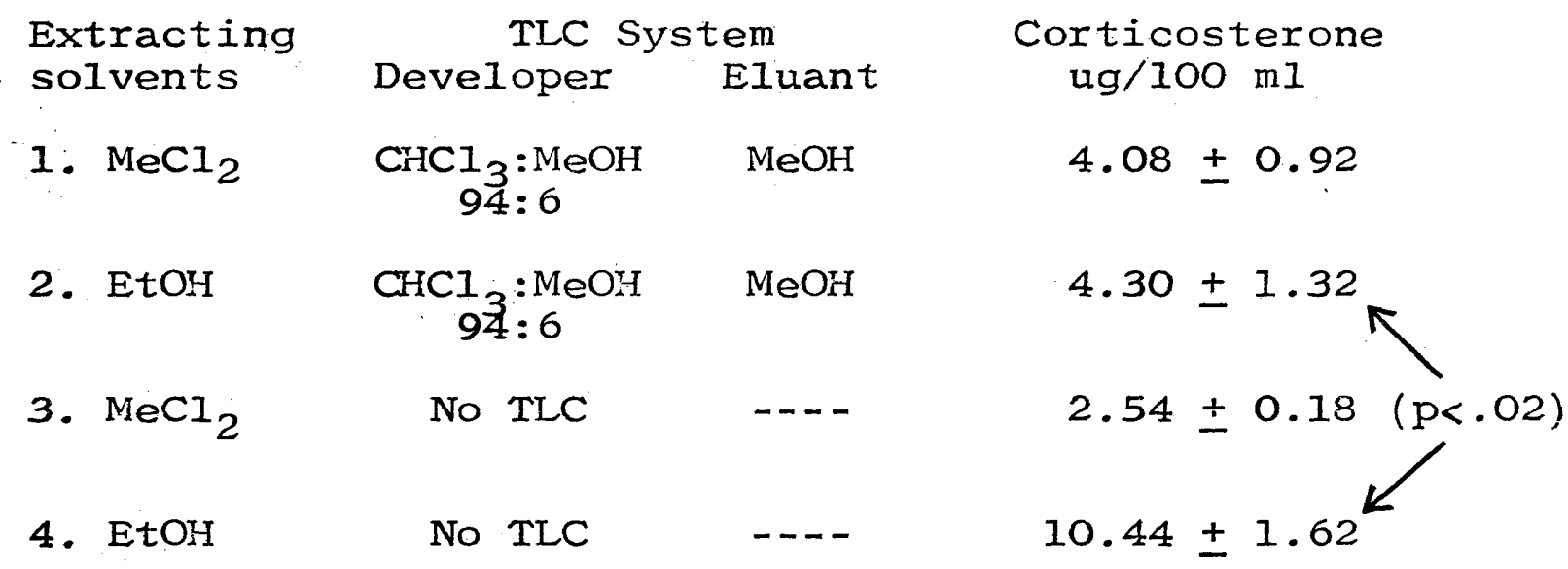

Thus, it appears that corticosterone levels established following extraction of the steroid with ethanol without TLC, as used by Bradshaw and Fontaine-Bertrand (1969) are high when compared with the other three methods. It also appears that addition of a this layer chromatography step does not add any advantages to the method, rather levels appear somewhat elevated. For these reasons, $\mathrm{MeCl}_{2}$ was used in these experiments.

VIII. STATISTICAL CHARACTERISTICS OF THE ASSAY

A. Sensitivity-

Sensitivity, or the smallest amount of corticosterone 
that could be significantly differentiated from zero, was calculated as suggested by Frankel et al. (1967):

$$
\text { Sensitivity }=t \times S / \sqrt{N}
$$

where $S$ = standard deviation, $N=$ number of determinations, and $t=$ Student's $t$ value for $\mathrm{N}-1$ degrees of freedom and the desired confidence. With 99.9\% confidence $(\mathrm{p}<.001)$, the sensitivity was $0.1 \mathrm{ng}$ corticosterone.

B. Precision-

Precision was determined from multiple determinations on samples taken from a common pool of $10 \%$ male rat plasma. No samples were determined simultaneously and the determinations were spaced over a seven day period. The mean of 23 samples was $3.80 \mathrm{ug} / 100 \mathrm{ml}$ plasma with a standard error of $0.08 \mathrm{ug} / 100 \mathrm{ml}$.

C. Recovery of radioactive corticosterone-

The mean and standard error of recovery of added $\mathrm{H}^{3}$ corticosterone from $\mathrm{MeCl}_{2}$ extraction of 31 lizard plasma samples was $89.7 \pm 1.4 \%$. In 18 extractions, $\mathrm{MeCl}_{2}$ removed $19.3 \pm 4.3 \%$ of the added $\mathrm{H}^{3}$-progesterone, a primary interferring steroid (see discussion).

D. Error-

Murphy (1967) has shown that the standard deviation of duplicate pairs increases in rough proportion to the steroid concentration, and is somewhat larger than $10 \%$ in the $0-10 \mathrm{ug}$ range. Counting errors ranged from 1 to $2 \%$ and counting 
background varied from 2 to $6 \%$. Both were regarded as negligible.

E. Blank values-

Unlike most other methods of corticoid assay in which large volumes of plasma must be extracted and numerous purification steps are employed, large blank values are not a problem. Water blanks consistently registered less than $0.1 \mathrm{ng}$ and were disregarded.

IX. STATISTICAL METHODS

All organ weights and plasma corticosterone levels were analyzed for significant differences using Student's't test for unpaired observations. Significance was determined to be the $95 \%$ level $(\mathrm{p}<.05)$ whereas a $\mathrm{p}<.01$ was considered highly significant. In the tables, all data are expressed as mean \pm standard error. 
RESULTS

I. THE EFFECI OF ADRENALECTOMY ON LIFE MAINTAINENCE

Of 33 adrenalectomized animals, 12 were alive 21 days after the operation. Of the animals that died, survival varied from 1 to 18 days.

II. VARIATIONS WITH SEASON (Table I)

Experiments were performed at different times of the year, and the control groups autopsied between November and May are shown in Table I. Corticosterone levels were similar until May, when a significant increase occurred ( $\mathrm{p}$ k. Ol compared to the April measurement). No significant changes in adrenal weights were observed during the same period. Testicular weights decreased significantly ( $\mathrm{p}<.001)$ from a high value in November of $1,240 \pm 90 \mathrm{mg} / 100 \mathrm{~g}$ to $238.7 \pm 62.1$ in January. A further decline occurred between January and February $(\mathrm{p}<.05)$ and thereafter testicular weight remained stable. Although some variations in body weight were observed, these did not correlate with any identifiable variables.

III. EFFECT OF A SINGLE INJECTION OF ACTH

A. In the intact animals (Figure III; Table III), the 
injection of $\mathrm{ACTH}$ had a marked and rapid effect on corticosterone levels which increased from a non-injected control value of $5.96 \pm 1.13$ to $11.32 \pm 1.08 \mathrm{ug} / 100 \mathrm{ml}$ plasma at 15 minutes and to $12.92 \pm 1.17$ at 30 minutes $(p<.01$ for both values compared to the control). Corticosterone levels decreased slightly from the high at 30 minutes to $9.18 \pm 1.10$ $\mathrm{ug} / 100 \mathrm{ml}$ at 60 minutes and $9.67 \pm 1.93$ at minutes. Both of these values were significantly higher than the control, however ( $\mathrm{p}<.02$ and $\mathrm{p}<.05$ respectively).

B. In the hypophysectomized group (Figure III; Table III), no change in the plasma corticosterone level occurred until 60 minutes after injection of $\mathrm{ACTH}$ when it reached $4.86 \pm$ $1.04 \mathrm{ug} / 100 \mathrm{ml}$ ( $\mathrm{p}<.02$ compared to control). By 90 minutes, the corticosterone level had dropped to $2.83 \pm 1.98 \mathrm{ug} / 100 \mathrm{ml}$ plasma. Although adrenal weights for the entire group were somewhat reduced from intact values, the reduction was not significant.

Comparing the control values for the two ACTH injection groups demonstrates the marked change in corticosterone concentration following hypophysectomy. From intact levels of $5.96 \pm 1.13 \mathrm{ug} / 100 \mathrm{ml}$, hypophysectomy induced a decline to $1.49 \pm 0.42 \quad(\mathrm{p}<.01)$.

IV. EFFECT OF LESIONS OF THE BRAIN (Figure IV; Table IV) The corticosterone level in the sham lesion group was $2.92 \pm 0.46 \mathrm{ug} / 100 \mathrm{ml}$ plasma. Lesions in the median eminence and anterior hypothalamus significantly depressed the cortico- 
sterone level compared to the sham operated $(1.06 \pm 0.33$; p<.01). Lesions of the anterolateral and posterior hypothalamus areas also reduced corticosterone levels significantly ( $1.66 \pm 0.17 ; \mathrm{p}<.02)$. Lesions of the cerebral hemisphere did not depress corticosterone levels. No changes in adrenal or testicular weights were observed.

V. EFFECT OF INHIBITORS (Figure V; Table V)

Injections of aminoglutethimide had no significant effect on either plasma corticosterone levels, relative adrenal weights, or relative testicular weights. However, cyano-ketone significantly depressed plasma corticosterone levels from 3.96 to 0.38 to $1.93+0.21 \mathrm{ug} / 100 \mathrm{ml}$ ( $\mathrm{p}<.001$ ) and also markedly increased adrenal weight ( $\mathrm{p}<.02)$. Testicular weights were unchanged. Metyrapone significantly increased corticosterone levels $(\mathrm{p}<.01)$ and caused a significant hypertrophy in the adrenals $(\mathrm{p}<.001)$. Adrenalectomy induced a drop in plasma corticosterone levels from a control value of $2.84 \pm 0.53$ to $0.40 \pm 0.30 \mathrm{ug} / 100 \mathrm{ml}(\mathrm{p}<.01)$.

VI. EFFECT OF CASTRATION AND ESTROGEN (Figure VI; Table VI) Estrogen injections significantly increased plasma corticosterone levels $(\mathrm{p}<. \mathrm{OI})$ and castration had no effect. However, estrogen injections in the castrate resulted in corticosterone levels almost identical to those of the controls and significantly lower than those of the estrogen treated group ( $p<.01)$. 

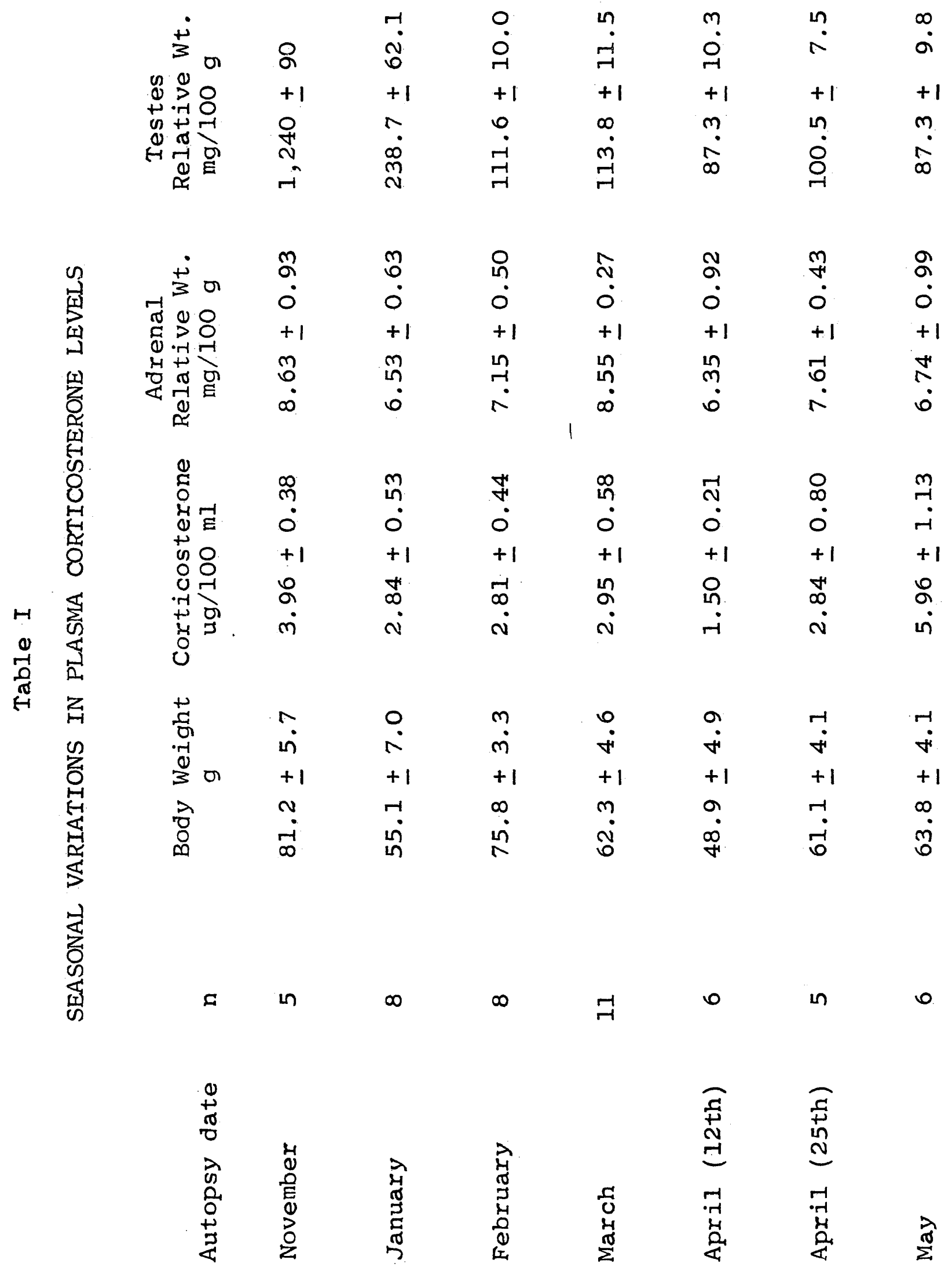


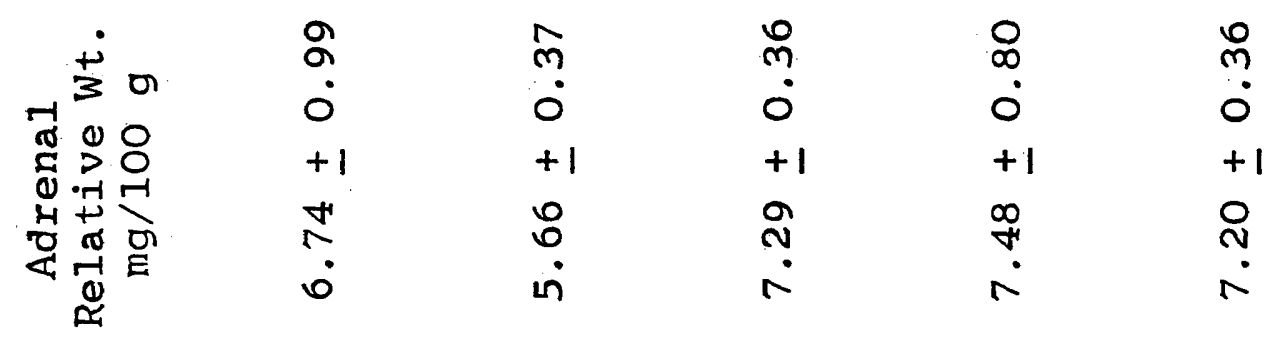
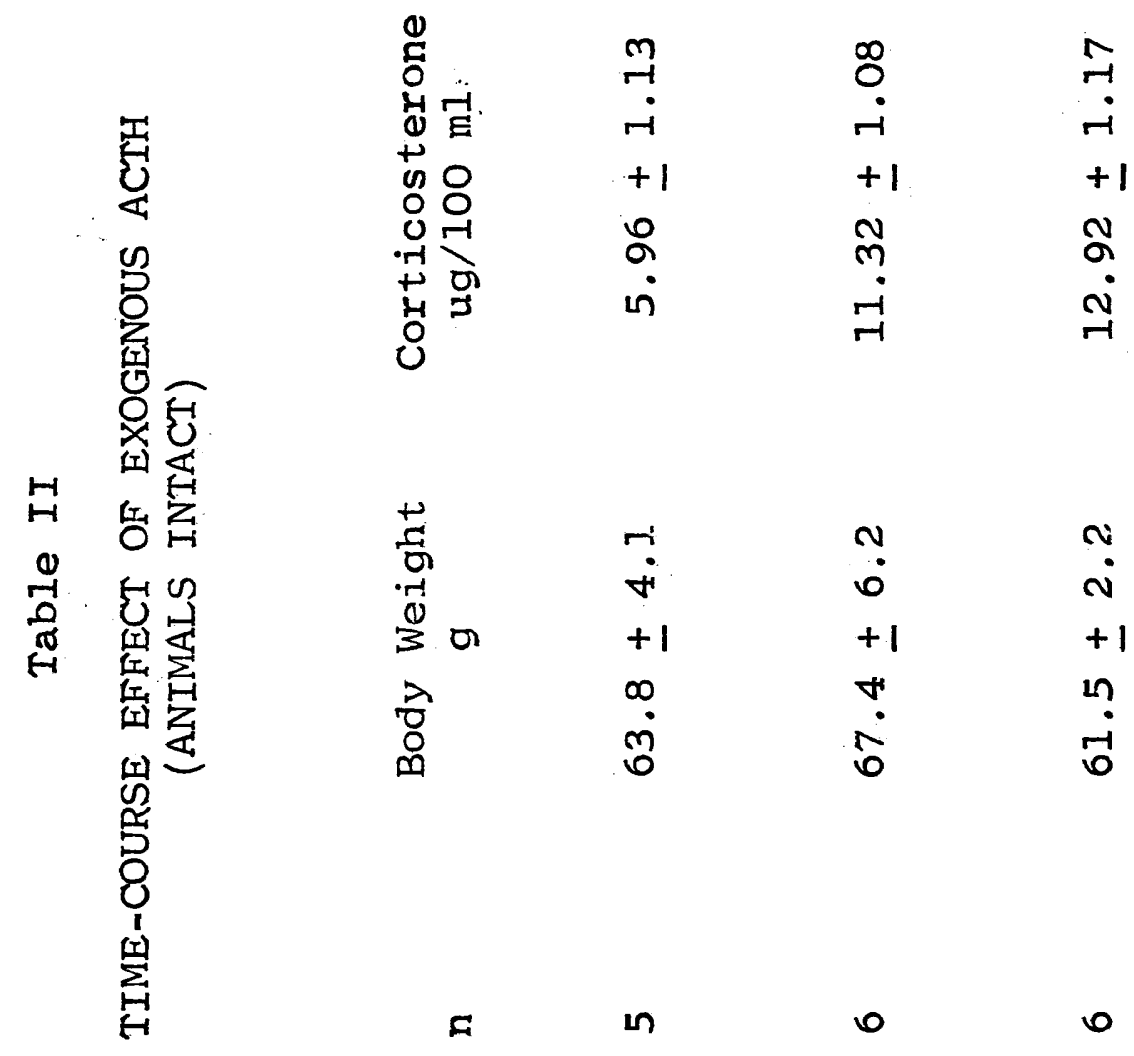

$\stackrel{0}{0}$

i

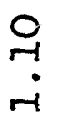

ตั

-i

$+1$

$+1$

๙ิ

i.

F

in

0

0

in

ก

$+1+1+1$

i

กิ

v

in

$\dot{0}$
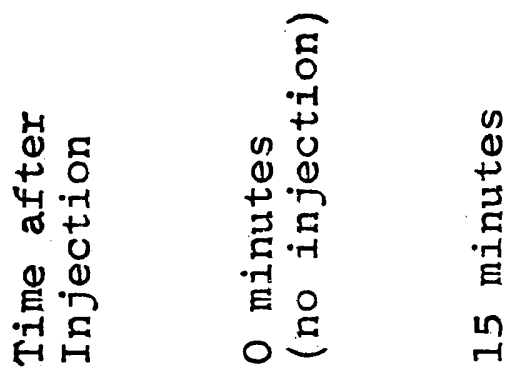

吕

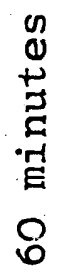

Oֶ) 


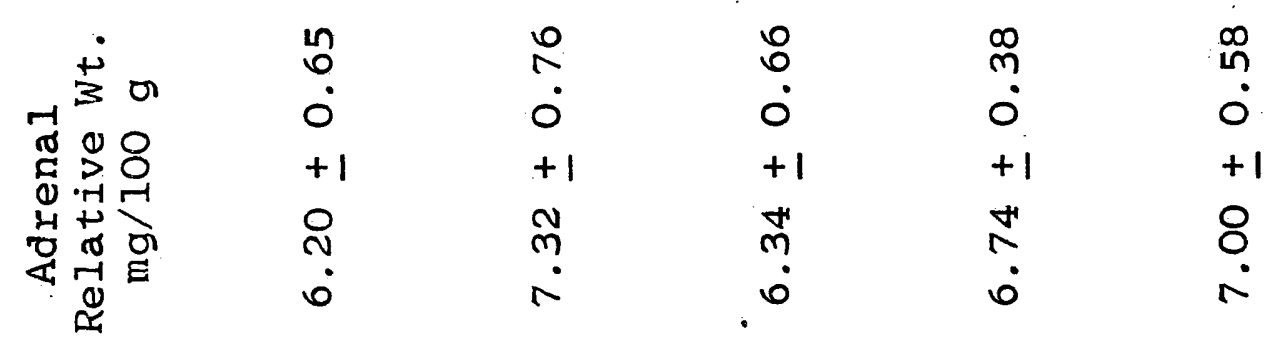
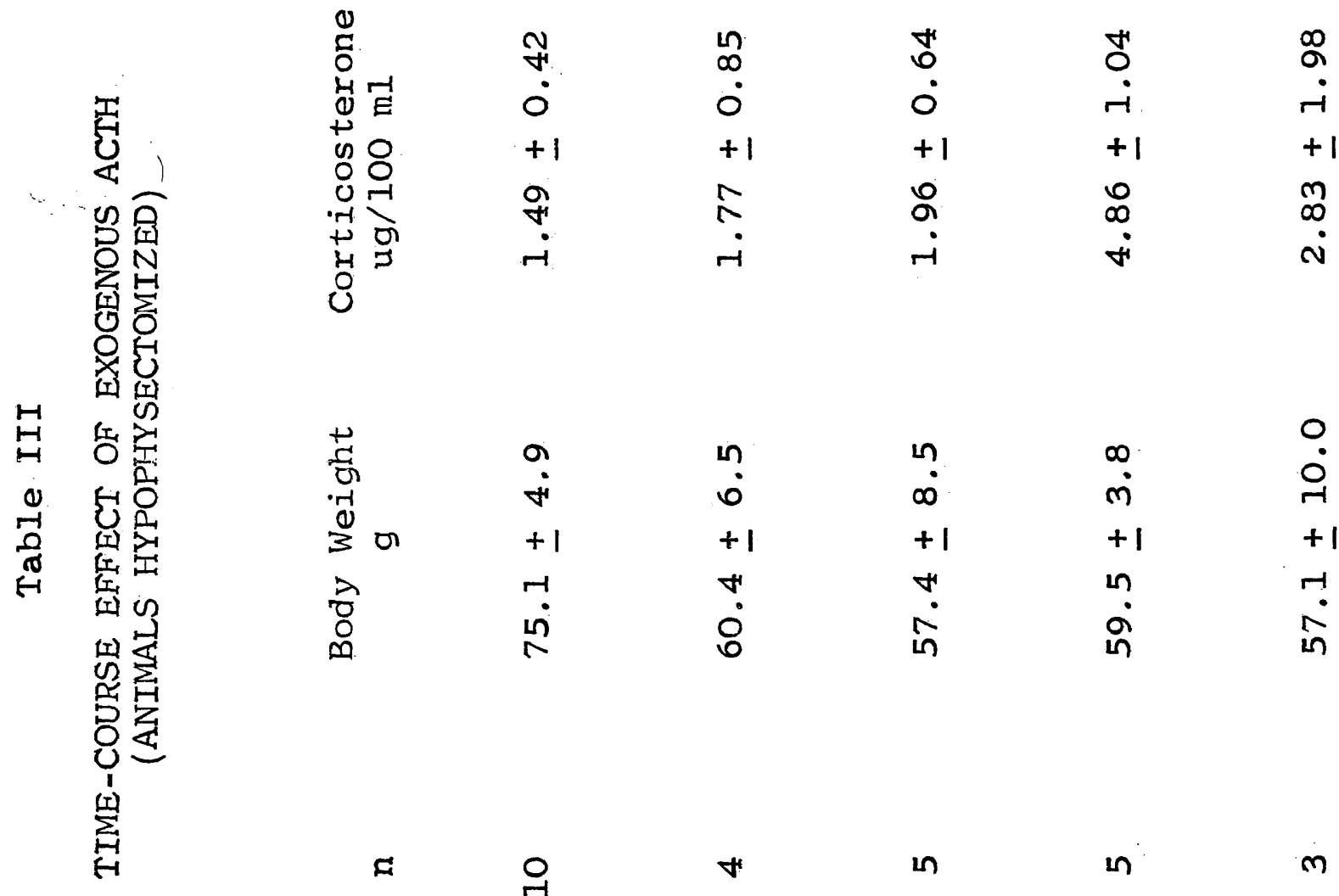

in

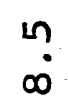

$\infty$

0

$+1+1$

$+1$

$+1$

$+1$

in

뭉

ก

in

in

a

거

$\forall$

in

in

$m$
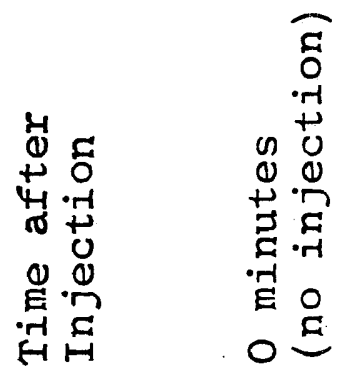

$\underset{\substack{0\\}}{\stackrel{n}{0}}$

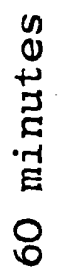

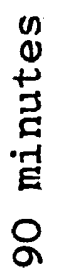



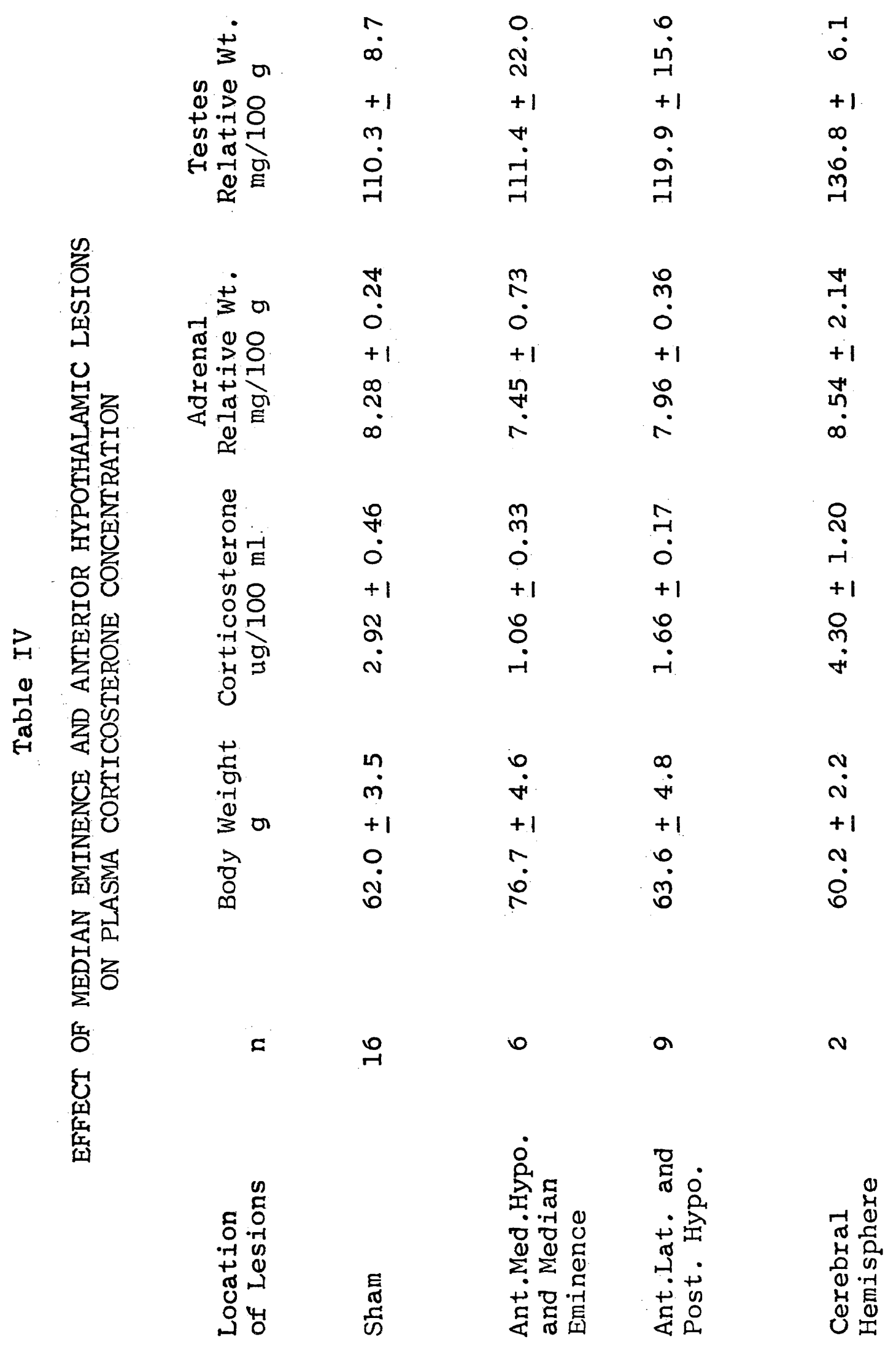


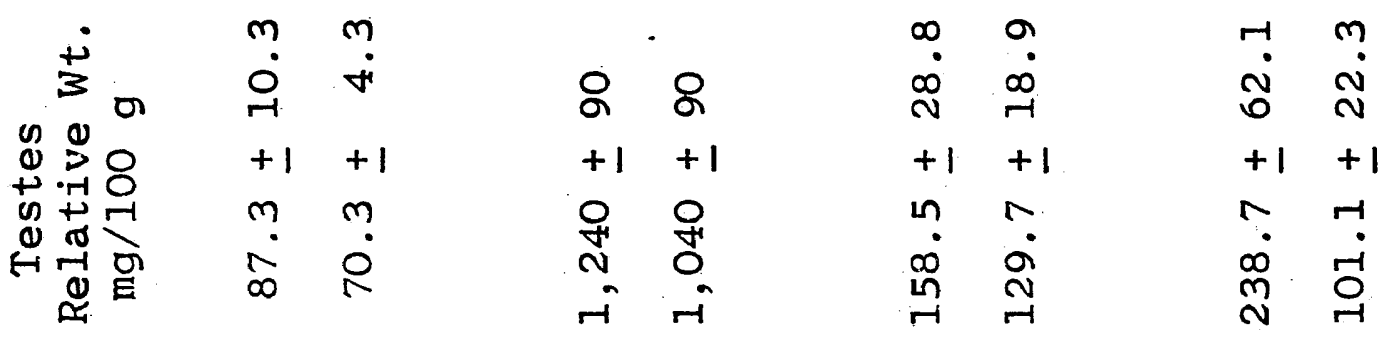

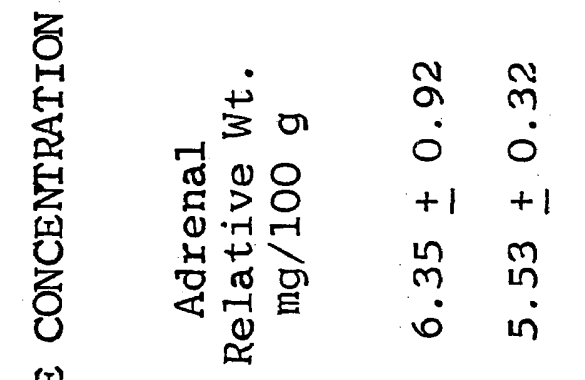

مै

$+1+1$

$m n$

$\infty \quad n$

$\stackrel{\infty}{m} \stackrel{-1}{v}$

$+1+1$

ฉั ๙ั

in $\quad \dot{v}$

$+1+1$

․

n $N$
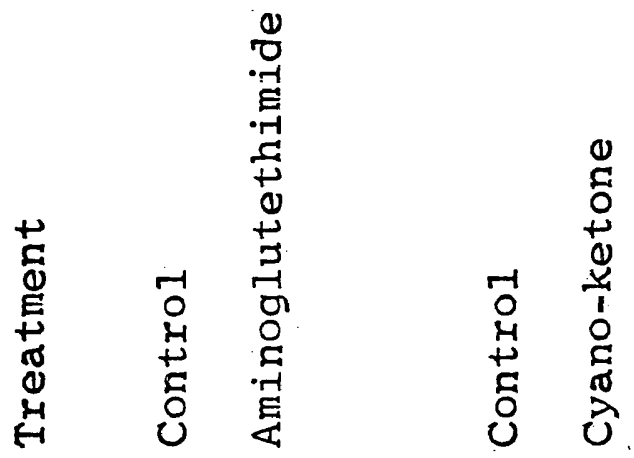

a 0 우

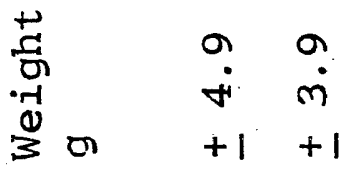

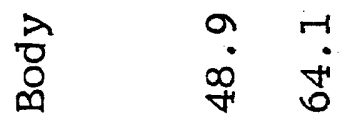

参

它 $\stackrel{\circ}{\stackrel{0}{0}}$ in

$+1+1$

$8 \%$

i $\dot{m}$

$\stackrel{0}{\circ}$

$+1+1$

in ñ

in

0 0

$+1+1$

ষ

N 0

i in

$+1+1$

in

N

$\infty m$

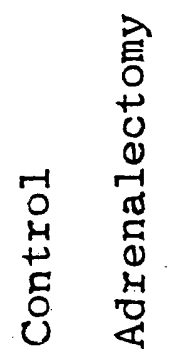



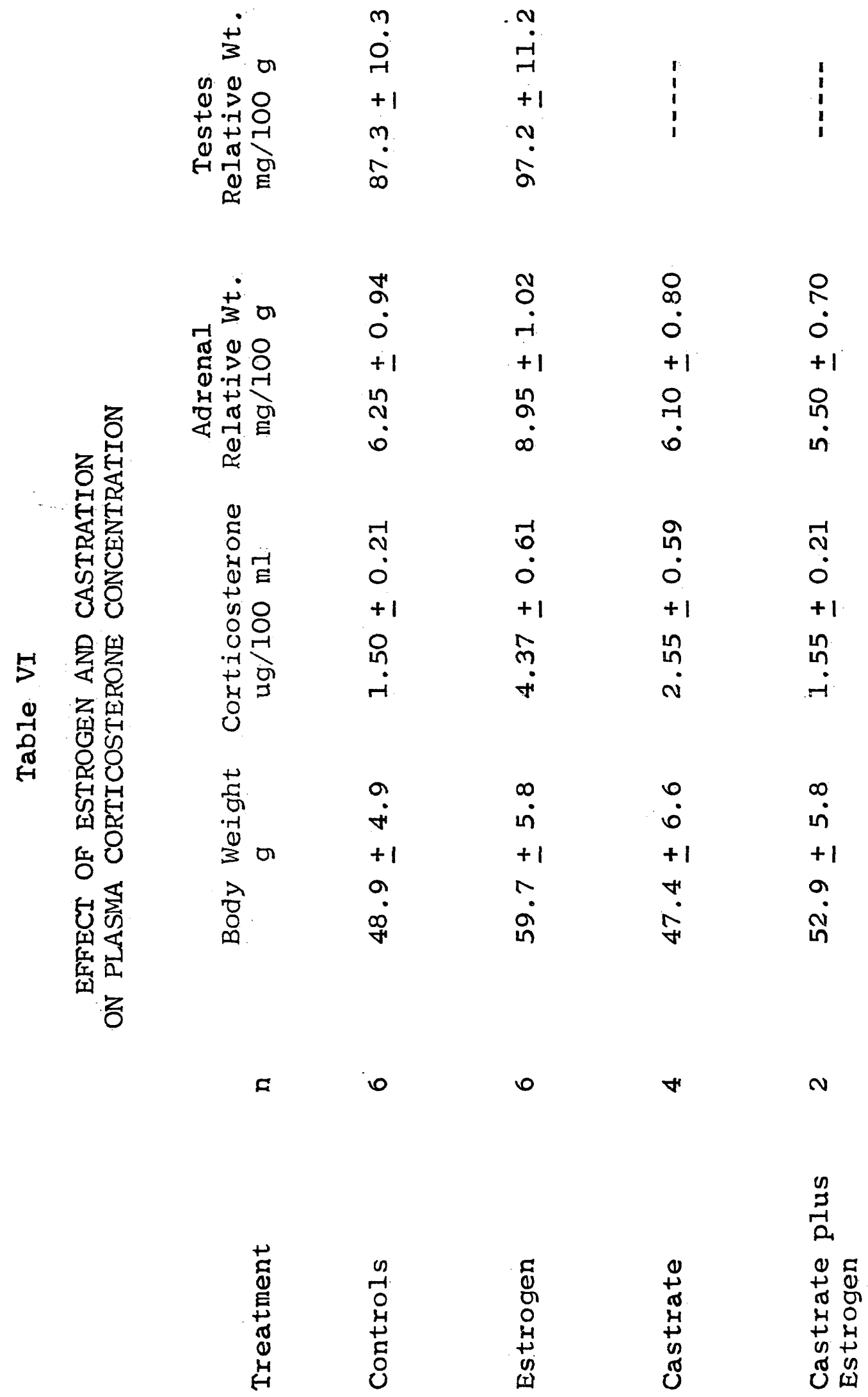
FIGURE I. The molecular configuration of aminoglutethimide, cyano-ketone, and metyrapone, inhibitors of adrenal corticosteroidogenesis. 
FIGURE I

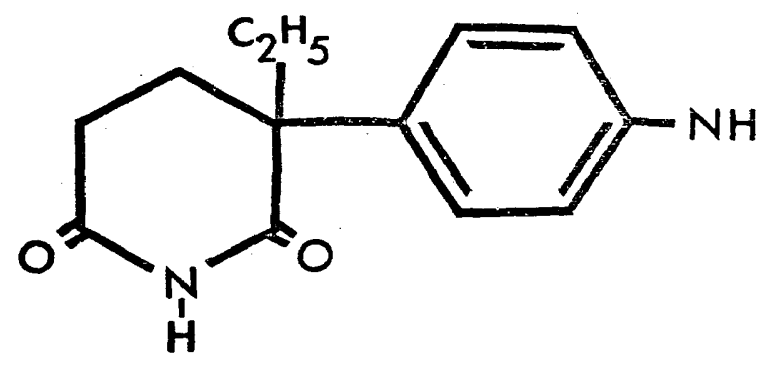

AMINOGLUTETHIMIDE

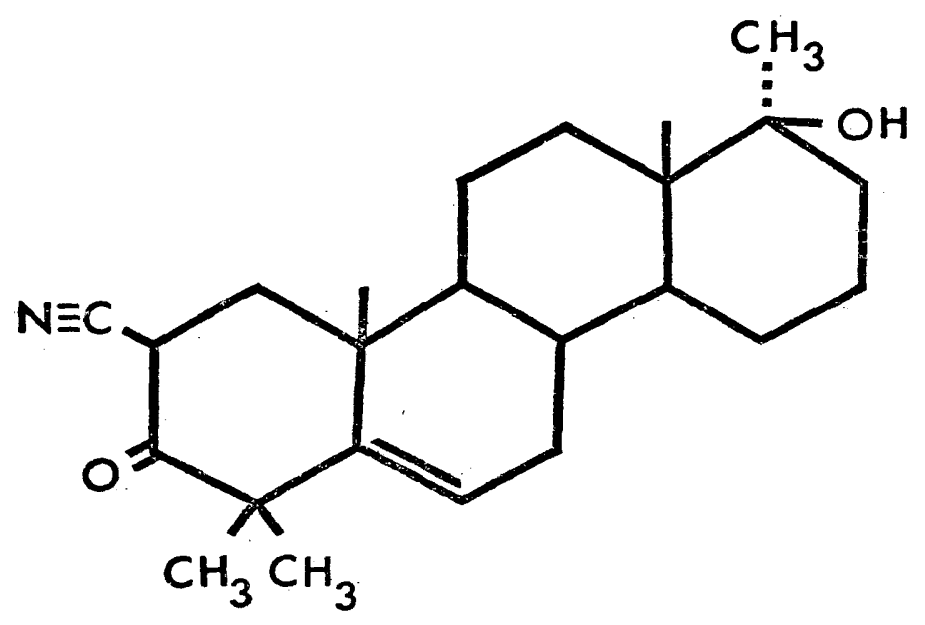

CYANO-KETONE

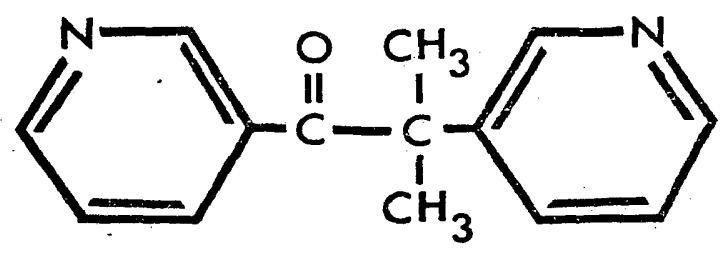

METYRAPONE 
FIGURE II. The standard curve. Brackets denote the standard error about the mean of 38 determinations. 
FIGURE II

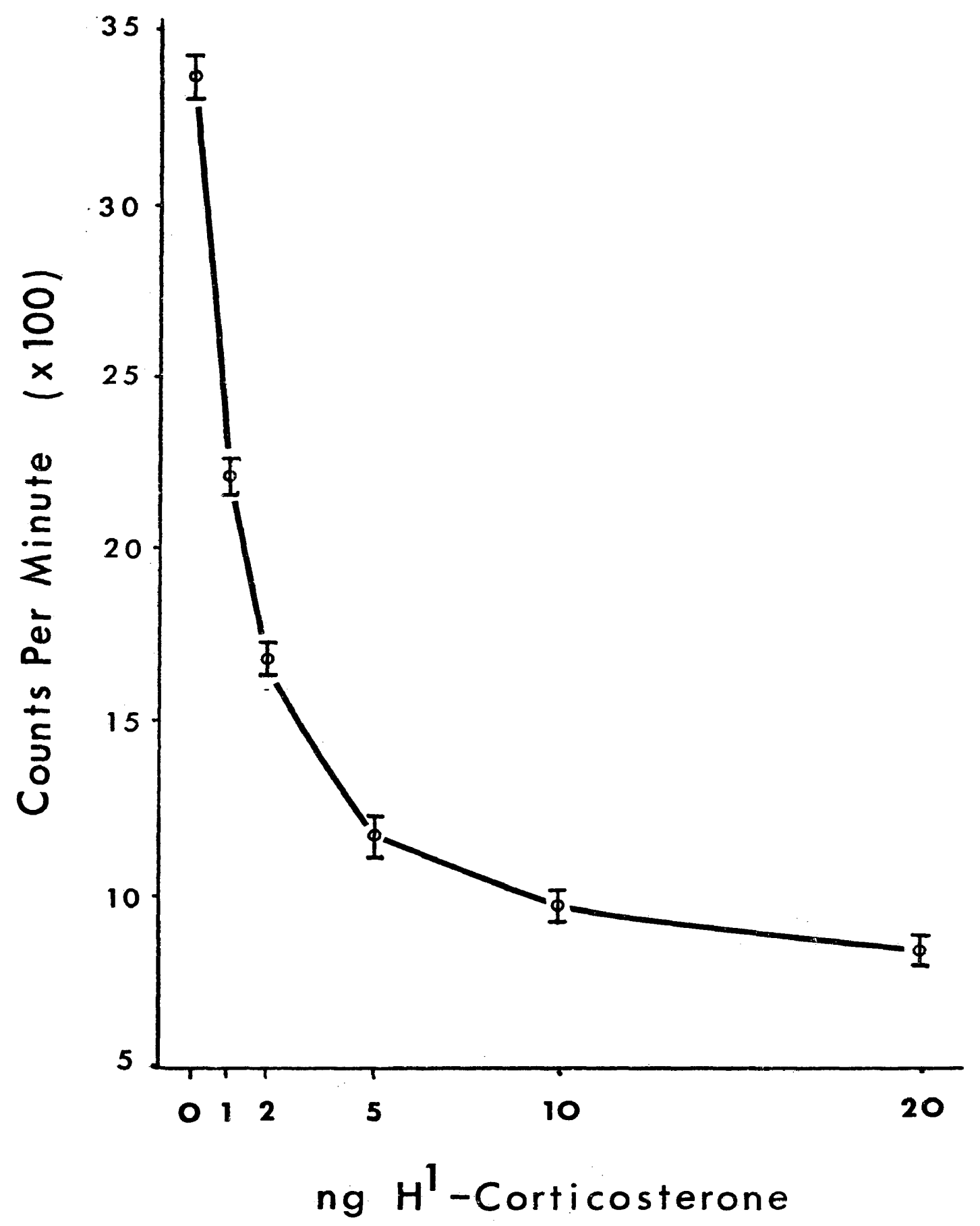


FIGURE III. Changes in plasma corticosterone concentration in intact and hypophysectomized Sceloporus cyanogenys following a single injection of 2 IU ACTH. Brackets denote the standard error about the mean. 
FIGURE III

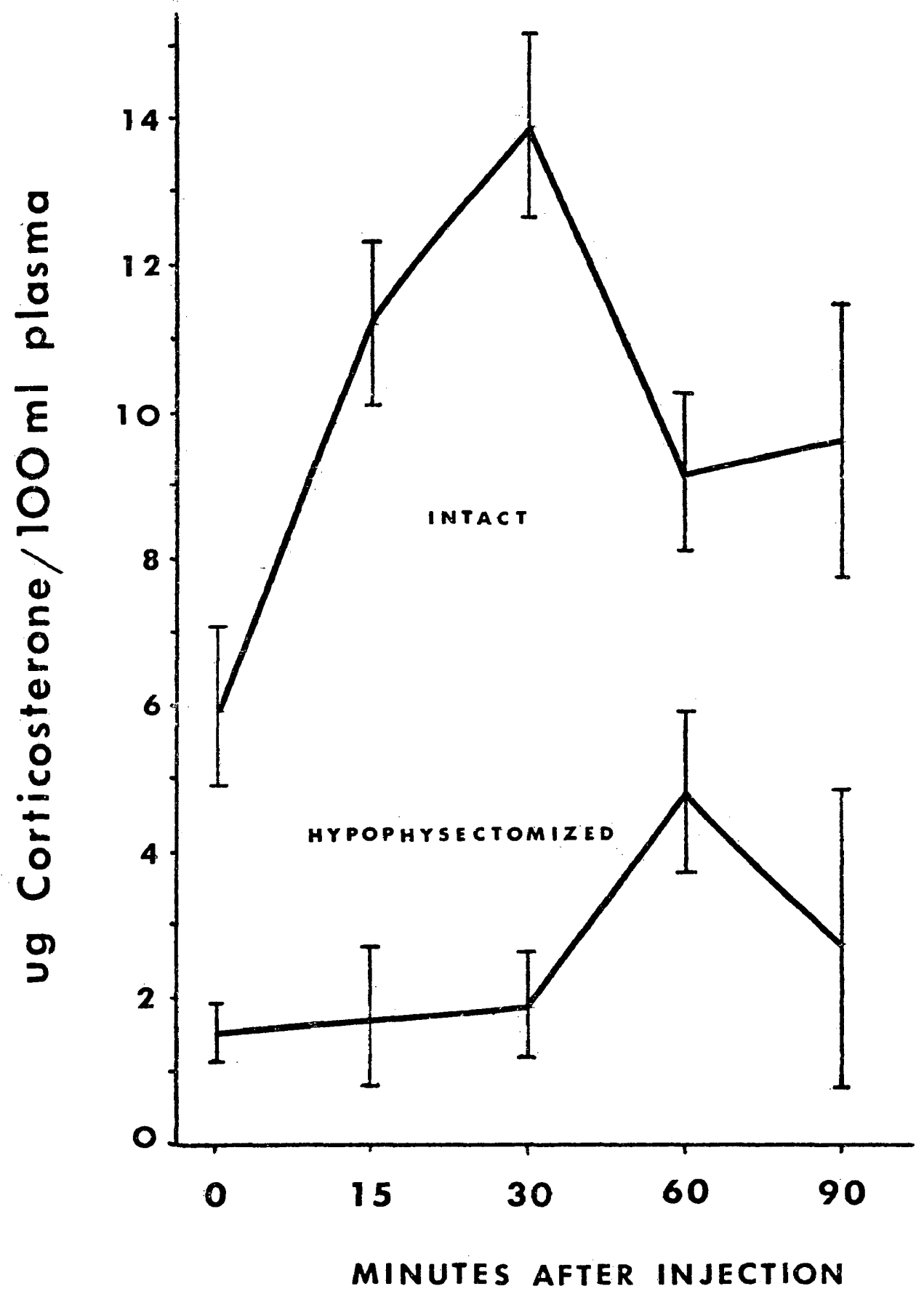


FIGURE IV. The effect of median eminence and anterior hypothalamic lesions on plasma corticosterone concentration in Sceloporus cyanogenys. Brackets denote the standard error about the mean. 
FIGURE IV

$$
\begin{aligned}
& \text { ME/AH - MEDIAN EMINENCE \& ANTEROMEDIAL HYPOTHALAMUS } \\
& \text { AL/PH - ANTEROLATERAL \& POSTERIOR HYPOTHALAMUS }
\end{aligned}
$$

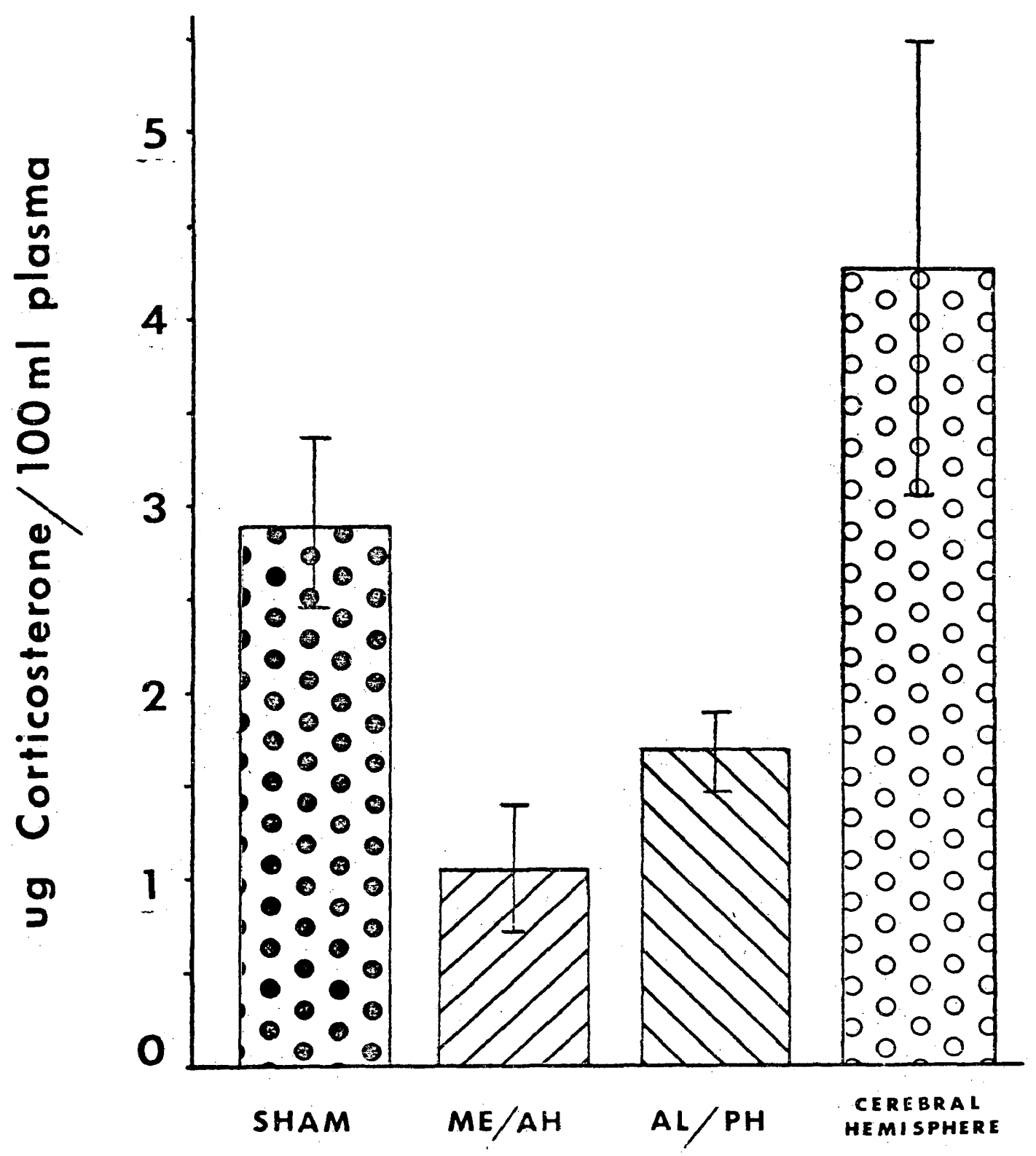


FIGURE V. The effect of inhibitors of adrenal corticosteroidogenesis on plasma corticosterone concentration in Sceloporus cyanogenys. Brackets denote the standard error about the mean. 
FIGURE V
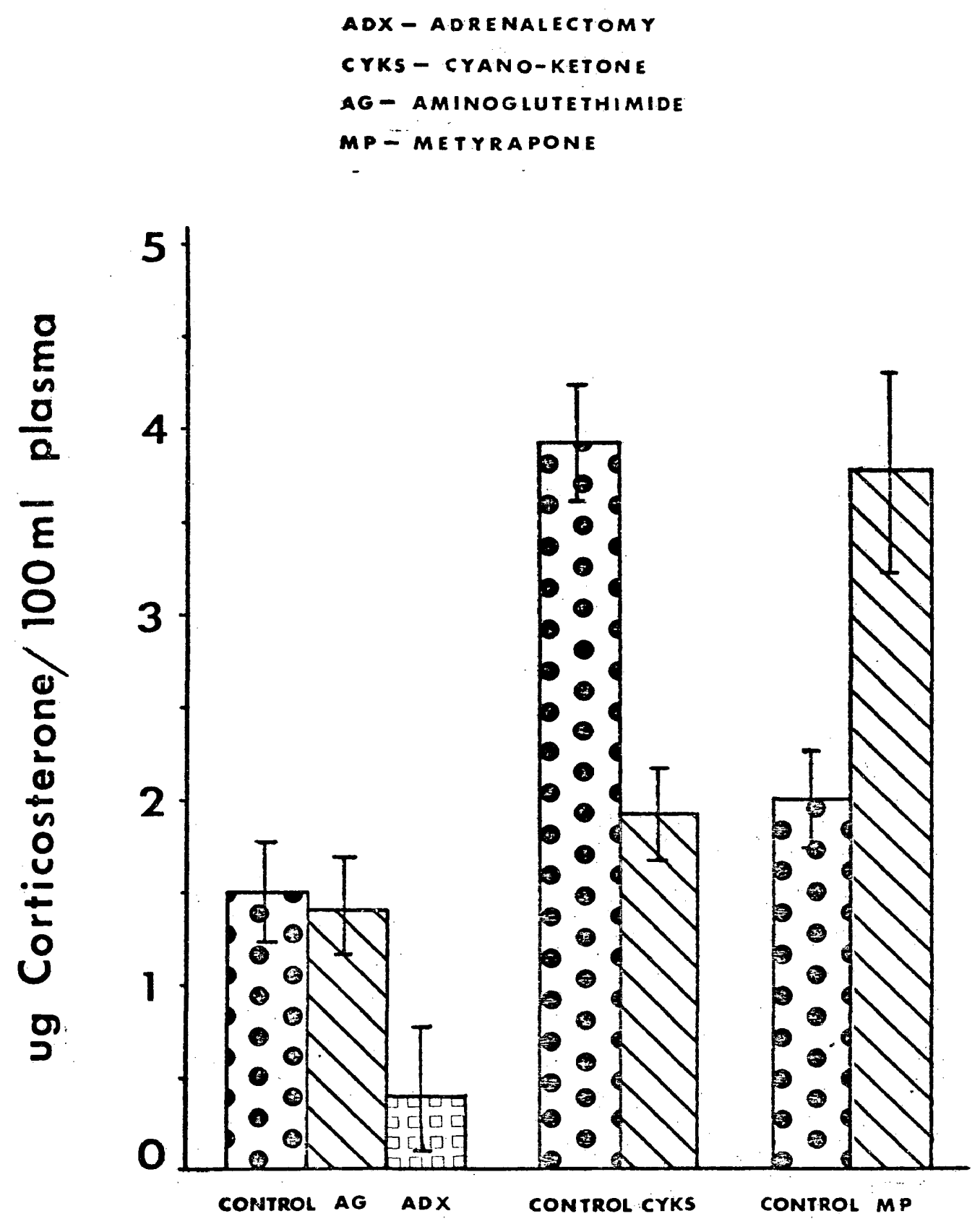
FIGURE VI. The effect of estrogen and castration on plasma corticosterone concentration in male Sceloporus cyanogenys. Brackets denote the standard error about the mean. 
FIGURE VI

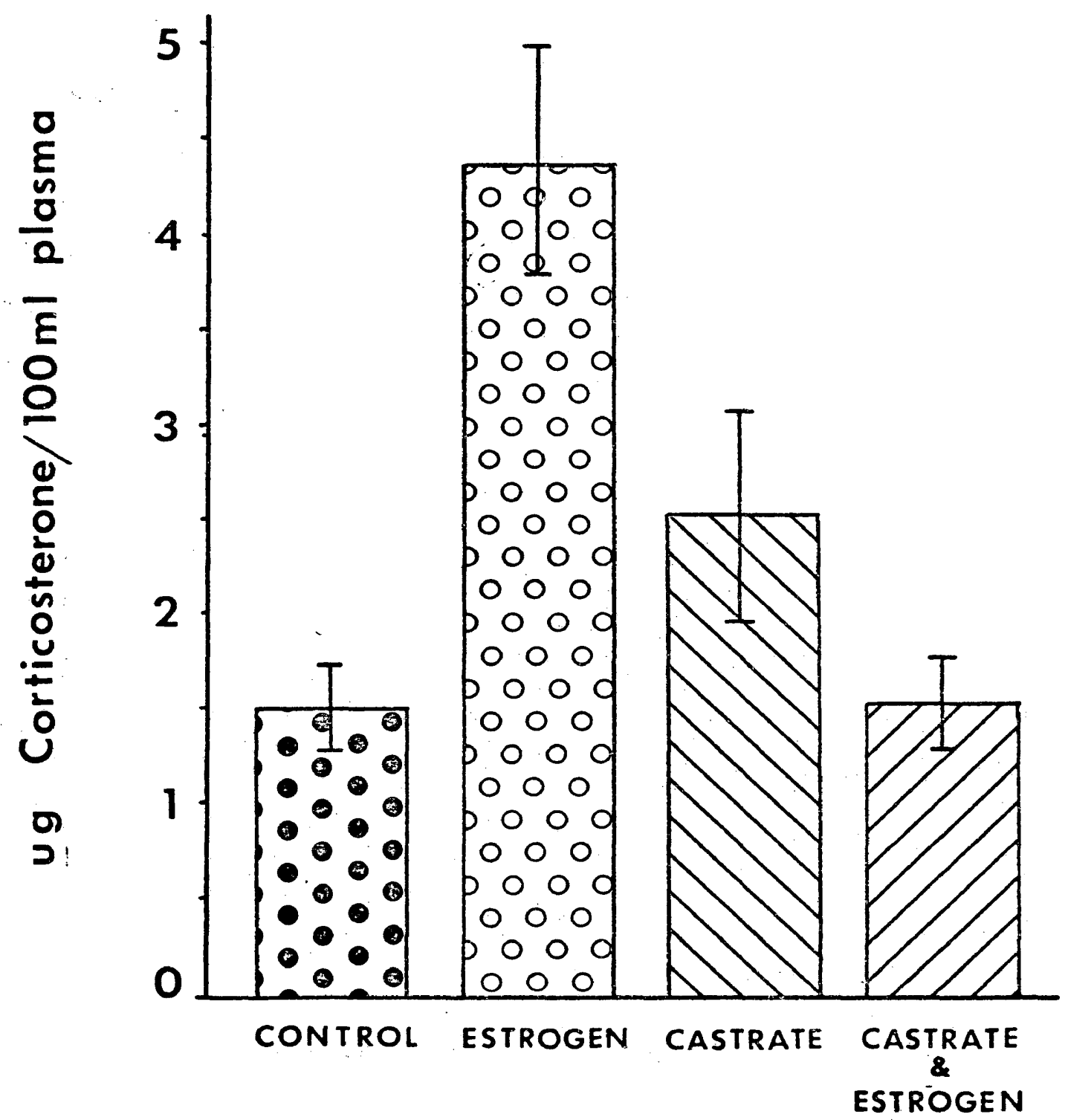




\section{DISCUSSION}

Corticosterone is the major glucocorticoid in reptiles as demonstrated in a number of in vitro investigations (Phillips et al., 1962, in Natrix natrix; Sandor et al., 1964: in a turtle; Macchi and Phillips, 1966, in Natrix; Gottfried et al., 1967 in the cobra; Macchi, 1966, in the grass snake and slider snake; and Gist and deRoos, 1966, in the alligator). Other steroids isolated from reptilian adrenal incubations are aldosterone (Gist and deRoos, 1966; Sandor et al., 1964; Gottfried et al., 1967), 18-hydroxycorticosterone (Sandor et al., 1964; Gottfried et al., 1967), deoxycorticosterone (Sandor et al., 1964; Huang et al., 1969), and cortisone (Gottfried et al., 1967). The presence of corticosterone in the blood of Natrix natrix was demonstrated by Chester-Jones et al., (1959) and more recently, quantitative estimates of circulating corticosterone levels have been reported in studies which utilized the competitive proteinbinding technique (Bradshaw and Fontaine-Bertrand, 1970; Licht and Bradshaw, 1969).

Methods for the determination of corticoids in blood were reviewed by Braunsberg and James (1961) and more recentIy by van der Molen (1970). Spectrophotometric and fluoro- 
metric techniques, although relatively simple, frequently lack the sensitivity to measure steroids in biological samples. Gas-chromatographic procedures are very sensitive but require extensive and intricate manipulations by experienced personnel. The isolation and characterization of corticosteroid-binding globulin (CBG, transcortin) as an $\alpha_{1}$-glycoprotein containing hexose, hexosamine, fucose, and sialic acid (Slaunwhite and Sandberg, 1959) opened the way for subsequent development of a sensitive assay for corticosteroids by Murphy (1967). The competitive protein-binding assay is highly sensitive, especially in the critical low ranges, and is unaffected by many substances which interfere with the colorimetric and fluorometric methods. This high sensitivity, the limit of which is determined primarily by the specific activity of the isotope, allows measurement to tenths of nanograms and thus facilitates the use of very small volumes of plasma.

A number of studies have shown agreement between corticosterone levels measured using the competitive protein-binding radioassay and other established procedures (Jones and Mason, 1966; Nugent and Mayes, 1966; Bowman and Deluna, 1968; Bradshaw and Fontaine-Bertrand, 1970). The technique is based on the competition between labelled and unlabelled corticosterone for the binding sites of the corticosteroid-binding globulin. Tritiated corticosterone is bound to the protein and subsequently quantitatively displaced by the unlabelled corti- 
costerone of the extracted samples. The assay is quantitated by counting the non-displaced labelled corticosterone.

In the present study, since no chromatography was done, the specificity in the assay was provided primarily by the binding globulin. Corticosterone, cortisol, 21-desoxycortisol, and 11-desoxycortisol all bind to the corticosteroidbinding globulin with comparable affinity. Several synthetic steroids, $\Delta^{1}$-cortisol, 2-methylcortisol, and $\Delta^{1}-16 \alpha$-hydroxycortisol, have also been labeled as strong competitors for the cortisteroid-binding globulin binding sites, whereas

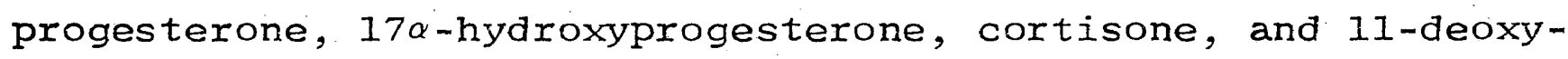
corticosterone bind far less avidly. Daughaday (1958) reported that the key molecular configurations in the binding of a steroid to corticosteroid-binding globulin are at least two hydroxyl groups at the $11 \beta, 17 \alpha$, or 21 positions and an intact $\Delta^{4}-3$-ketone moiety in the A ring. Estrogens and androgens are bound only weakly, if at all, by transcortin (Slaunwhite and Sandberg, 1959). Aldosterone is also bound very weakly by $\mathrm{CBG}$ and along with Il-hydroxyandrostenedione, progesterone, 3,17-dihydroxypregnane-11,20-dione, pregnane3,11,20-trione, dehydroisoandrosterone, and androstenedione have albumin as their major binding protein (Chen et al., 1961). Albumin also bind quantities of corticosterone, but with low affinity. With the binding plasma drastically diluted, the effects of albumin binding of corticosterone become minimal. 
Early studies utilizing adrenal weight as an index of circulating ACTH levels demonstrated the presence of a pituitary adrenal axis in reptiles (Shaeffer, 1933; Wagner, 1955; Wright and Chester-Jones, 1957; Chan et al., 1970). Only recently have reptilian studies confirmed the importance of a hypothalamo-adenohypophyseal interrelation for normal adrenal function in lizards. Using the metyrapone treated Iizard Sceloporus cyanogenys, Callard and Willard (1969) demonstrated that betamethazone implants in the hypothalamus prevented metyrapone induced adrenal hypertrophy and also decreased adrenal $\Delta^{5}-3 \beta$-hydroxysteroid dehydrogenase activity. In 1971, Callard and Chester-Jones demonstrated that lesions of the median eminence and anteromedial hypothalamus also prevented the adrenal hypertropic response to metyrapone. Thus, on the basis of adrenal weight, histology, and histochemistry, it appears that neuronal elements in the anteromedial hypothalamus and median eminence are involved in the control of the pituitary-adrenal axis. Mammalian studies have demonstrated a similar role for the hypothalamus in adrenal control. (Fortier, 1966; Ganong, 1959; Brodish, 1961; Fortier and deGroot, 1964; Davidson and Feldman, 1963; Ramirez et al., 1964).

In demonstrating that lesions of the anteromedial hypothalamus and median eminence decrease peripheral corticosterone levels in the lizard, the suggested role of the hypothalamus in the reptilian system is substantiated. The 
suppression of corticosterone levels by anterolateral and posterior hypothalamic lesions noted here, was not paralled by a reduction of the metyrapone induced adrenal hypertrophy by similar lesions in the study of Callard and Chester-Jones (1971). Cerebral hemisphere lesions, although few in number, had no suppressive effect on corticosterone levels. This study emphasizes the need to use functional criteria of adrenal function as opposed to morphological criteria where possible.

In this study, hypophysectomy reduced the basal level but did not eliminate steroid output. In the rat and other mammals, hypophysectomy typically reduces plasma corticoid levels to a much greater degree (Fortier, 1966). This may indicate a lesser dependence of the lizard adrenal on pituitary ACTH than shown in the mammal. Further, the adrenal response to ACTH in the hypophysectomized animals was qualitatively and quantitatively different from that in the intact animal. The delayed appearence of ACTH stimulated secretory activity in the hypophysectomized animals can possibly be explained on the basis of the superimposition of the ACTH effect on the basal level of synthesis and secretion. Since ACTH stimulates the entire steroidogenic process through its early action on the NADPH dependent steps, especially the conversion of cholesterol to pregnenolone (Ganong, 1967), one might expect the steroid biosynthetic machinery of the intact animal to be readily activated. In the hypophysecto- 
mized animal, however, metabolic intermediates and key enzymes may be present in subnormal quantities thus resulting in a delay of the activation of the system and a quantitatively poor response. Possibly also, the absence of other pituitary hormones, particularly STH, known to be synergistic in its action with other hormones (Turner, 1966), is of importance in the response obtained to ACTH alone in the hypophysectomized animal.

The response to ACTH obtained in this study may be compared with those obtained by Licht and Bradshaw (1969) in dexamethazone suppressed Anolis. With $50 \mathrm{mU}$ ACTH, they elicited a marked increase in corticosterone titers within 15 minutes, with a peak at 30 minutes followed by a rapid decline to basal levels by 60 minutes. This initial rise is qualitatively identical to the response of the intact group in the present study, but the magnitude of the response was far greater than could be shown in Sceloporus, which maintained a significant elevation past 90 minutes. In the Anolis study, pituitary ACTH secretion was suppressed with dexamethazone whereas the pituitary was totally removed in the present investigation. The difference in the time and magnitude of response emphasizes the importance of other pituitary hormones, possibly STH, in maintaining the adrenal in a ready state as well as synergizing with ACTH once it becomes available. The studies of Licht and Bradshaw (1969) also demonstrate a response of the adrenal gland of Anolis 
to Anolis pituitary extracts. Therefore, it seems clear that the pituitary-adrenal axis of reptiles is qualitatively similar to that of mammals, perhaps differing somewhat in the speed of response to ACTH.

The use of inhibitors of steroid biosynthesis has facilitated the study of hypothalamo-adenohypophyseal-adrenal interactions in Iizards (Callard and Willard, 1969; Callard and Chester-Jones, 197I) as in other vertebrates (Olivereau, 1965; Van Kemenade and van Dongen, 1965: Gaunt et al., 1965). In this study, several inhibitors of steroidogenesis were employed to evaluate their degree of suppression of the adrenal gland. One substance, cyano-ketone, a $\Delta^{5}$-3 $\beta$-hydroxysteroid dehydrogenase inhibitor (Ferrari et al., 1963; Goldman et al., 1965) had a marked effect, reducing corticosterone levels to those found in the hypophysectomized animals and increasing adrenal weight 100\%. In correlated studies, cyano-ketone has been demonstrated to decrease both Iiver glycogen and biood glucose (Gerstle, 1971), both indices of glucocorticoid activity. Aminoglutethimide, an inhibitor of the cholesterol to pregnenolone synthetic step (Gaunt et al. 1968), was ineffective in the suppression of corticosterone secretion and did not influence ACTH output as indicated by adrenal weight. It is possible that both the dose and time period selected were inappropriate.

Metyrapone, an $11 \beta$ hydroxylase inhibitor (Chart and Sheppard, 1959), while causing an increase in adrenal weight, 
did not suppress, but rather elevated "corticosterone" levels in the blood. It is possible that under increased ACTH stimulation, large quantities of the II $\beta$ hydroxylase substrate, deoxycorticosterone, the immediate precursor of corticosterone, and progesterone, a key intermediate, might "pool" in the gland and enter the blood in large quantities. Since both of these steroids have been shown to bind to CBG, in the absence of corticosterone, these steroids could displace labelled corticosterone from the CBG and appear as "corticosterone" in the assay. Butler and Knox (1970) have suggested a similar mechanism for the absence of an influence of metyrapone on electrolyte levels in turtles. As with cyano-ketone, both liver glycogen and blood glucose levels were depressed following metyrapone, but to a lesser extent than with cyano-ketone. This supports the postulate that corticosterone is suppressed even though higher "corticosterone" values are obtained.

The wide variability in length of survival following adrenalectomy in this study seems to be in concert with findings reported previously for adrenalectomy in reptiles. Adams and Harland (1929) showed survival times of 8 hours to 6 days in Anolis, while Kleinholz (1938) could maintain the same species for only 10 to 24 hours. Three large iguanas lived for 11 and 24 hours and 5 days following adrenalectomy (Holmberg and Soler, 1942). In a study on adrenalectomized snakes, Valle (1945) found that 16 of 18 animals survived 
for seven days. Recently, Elizondo and LeBrie (1969) reported Iimited success with adrenalectomy by cautery, survival being from 10 to 48 hours in the snake, Natrix. Turtles have been kept for up to two weeks after adrenalectomy for electrolyte studies by Butler and Knox (1970).

The surgical difficulties noted in the above work were experienced in the present study. Identical weight related doses of Nembutal produced varying degrees of anesthesia. Hemorrhage during the destruction of the adrenal varied from slight to massive regardless of care taken. However, the extent of bleeding and apparent surgical trauma appeared to have little correlation with actual survival.

Adrenal cortical hypertrophy during the reproductive period in reptiles has been noted in Lacerta agilis (Bimmer, 1950), Thamnophis elegans (Fox, 1952), Xantusia vigilis (Miller, 1955), Lacerta vivipara (Panigel, 1956), Vipera aspis (Martoja et al., 1961), and in the slow sorm, Anguis fragilis (Saint Girons, 1963). Lofts et al. (1971) showed that in the cobra, Naja naja, adrenal weight increases rapidIy in March and April as the snake enters its reproductive season. The weight peaks in June and then gradually declines for the remainder of the season with a partial recovery in October during cortical hyperplasia and recrudesence of spermatogenic activity on the seminiferous tubules (Lofts et al., 1966).

In the present study, adrenal weights did not vary 
between November and May and levels of circulating corticosterone were also relatively constant during that time, although data from December, the height of the breeding season, are not available. The sharp rise in corticosterone levels in May might be correlated with increased activity during the spring.

Sex differences in adrenal weight have been observed in lizards and adrenal glands of other iguanid lizards respond to estrogen treatment with increases in weight (Callard and Callard, in preparation). In the present study, there appears to be an increase in adrenal secretion in the spring, possibly related to increased activity. Injection of estrogen into males indicated that this steroid may enhance adrenal activity in the lizard.

Kitay (1968), in a report of the effect of estrogen and castration on plasma corticosterone concentrations in the rat, noted somewhat elevated values following estrogen treatment and a possible slight elevation in sonadectomized males. Callard and Leatham (1963) found that orchidectomy in the rat increases peripheral corticosterone levels by about $30 \%$ and estrogen treatment of either the intact or castrate perpetuates a three fold increase. Colby and Kitay (1971) demonstrated in the rat that estradiol increased corticosterone levels and decreased the activity of 5 reductase, a principal enzyme in the catabolism of corticosterone. The present study suggests a like effect of estrogen in the 
lizard. However, whereas in the mammals, this effect appeared to be independent of the gonad, both corticosterone and adrenal weight data here indicate that in the male reptile estrogen induced adrenal hypersecretion and hypertrophy may be facilitated by the testes.

These studies substantiate, with direct estimation of corticosterone, the principal glucocorticoid of the reptilian adrenal, earlier work (Callard and Willard, 1969; Callard and Chester-Jones, 1971) strongly suggesting the presence of a hypothalamo-adenohypophyseal-adrenal axis similar to that found in mammals (Fortier, 1966). The responses of this adrenal control system to physiological manipulations, such as adrenal inhibitors, hypophysectomy, and corticotropin administration, are qualitatively similar to known mammalian responses, indicating phylogenetic constancy of the control system for adrenal function. 
BI BLI OGRAPHY 


\section{BIBLIOGRAPHY}

Adams, A.E., and Harland, M. (1929). The effects of adrenalectomy in lizards. Anat. Rec. 41, 42.

Bimmer, E. (1950). Metrische Untersuchungen uber die Entwicklung der Nebenniere und der ihr benachbarten Organe die Eidechsen. Anat. Anz. 97, 276-311.

Bowman, R.E., and Deluna, R.F. (1968). Assessment of a protein-binding method for cortisol determination. Ana1. Biochem. 26, 465-469.

Bradshaw, S.D., and Fontaine-Bertrand, E. (1969). Measurement of corticosteroids in reptilian and avian plasma by fluorometry and by competitive protein binding radioassay. Comp. Biochem. Physiol. 36, 37-48.

Braunsberg, H., and James, V.T.H. (196I). The determination of cortisol and corticosterone in blood: a review. Jour. Clin. Endocr. Metab. 21, 1146.

Bray, G.A. (1960). A simple efficient liquid scintillator for counting aqueous solutions in a liquid scintillation counter. Anal. Biochem. 1, 279-285.

Brodish, A. (1961). Diffuse hypothalamic system in the regulation of ACTH release. Proc. Endocrine Soc. 43,2 .

Butler, D.G., and Knox, W.H. (1970). Adrenalectomy of the painted turtle (Chrysemis picta belli): effect on ionoregulation and tissue glycogen. Gen. Comp. Endocr. $14,551-566$.

Callard, G.V., and Leatham, J.H. (1963). Gonadal influences on adrenal function. Am. Zool. 3, 501 .

Callard, I.P., and Callard, G.V. (in preparation).

Callard. I.P., and Chester-Jones, I. (1971). The effect of hypothalamic lesions and hypophysectomy on adrenal weight in Sceloporus cyanogenys. Gen. Comp. Endocr. (in press). 
Callard, I.P., and Willard, E. (1969). Effects of intrahypothalamic betamethazone implants on adrenal function in male Sceloporus cyanogenys. Gen. Comp. Endocr. $13,460-467$.

Chan, D.K.O., Callard, I.P., and Chester-Jones, I. (1970). Observations on the water and electrolyte composition of the iguanid lizard Dipsosaurus dorsalis (Baird and Girard) with special reference to the control by the pituitary gland and the adrenal cortex. Gen. Comp. Endocr. 15, 374-387.

Chart, J.J., and Sheppard, H. (1959). Pharmacology and biochemistry of some amphenone analogues and other adrenal cortical inhibitors. Jour. Med. Pharm. Chem. 1,5 .

Chen, P.S., Mills, I.H., and Bartter, F.C. (1961). Ultrafiltration studies of steroid-protein binding. Jour. Endocr. 23, 129-137.

Chester-Jones, I., Phillips, J.H., and Holmes, W.N. (1959). Comparative physiology of the adrenal cortex. In "Comparative Endocrinology." (A. Borgman, ed.) pp. 582612. Wiley, New York.

Colby, H.D., and Kitay, J.I. (1971). Interaction of testosterone and estradiol with ACTH in the regulation of adrenal corticosterone production in the rat. Proc. 53rd Meeting Endocr. Soc. P. A-49.

Daughaday, W.H. (1958). Binding of corticosteroids by plasma proteins. III. The binding of corticosteroids and related hormones by human plasma and plasma protein fractions as measured by equilibrium dialysis. Jour. Clin. Invest. $37,511-518$.

Davidson, J.M., and Feldman, S. (1963). Cerebral involvement in the inhibition of ACTH secretion by cortisone. Endocrinol. 72, 696-712.

Elizondo, R.S., and LeBrie, S.J. (1969). Adrenal-renal function in water snakes Natrix cyclopion. Am. Jour. Physiol. 217, 419-425.

Ferrari, R.A., and Arnold, A. (1963). Inhibition of $\beta$-hydroxysteroid dehydrogenase. I. Structural characteristics of some steroidal inhibitors. Biochem. Biophys. Acta 77, 349-356.

Fortier, C. (1966). Nervous control of ACTH secretion. In "The Pituitary Gland." Vol. 2, p. 195. Univ. Calif. Press, Berkeley. 
Fortier, C., and deGroot, J. (1964). Effect of localized destruction of the ventral hypothalamus on the adrenocorticotrophic responses to surgical trauma and to hypocorticoidism in the rat. In "Major Problems" in Neuroendocrinology." (E. Bajusz and G. Jasmin, eds.), pp. 220-229. Karger, Basel.

Fox, M. (1952). Seasonal variations in the male reproductive system of the Pacific coast garter snakes. Jour. Morphol. 90, 481-554.

Frankel, A.I., Cook, B., Graber, I.W., and Nalbandov, A.V. (1967). Determination of corticosterone in plasma by fluorometric techniques. Endocrinol. 80, 181-194.

Ganong, W.F. (1959). Adrenal-hypophysial interrelations. In "Comparative Endocrinology." (A. Gorbman, ed.), pp. 187-201. Wiley, New York.

Ganong, W.F. (1967). The adrenal medulla and cortex. In "Review of Medical Physiology.", P. 299. Lange Medical Publications, Los Altos, Calif.

Gaunt, R., Chart, J.J., and Renzi, A.A. (1965). Inhibitors of adrenal cortical function. In "Reviews of Physiology, Biochemistry, and Experimental Pharmacology." Springer, BerIin.

Gaunt, R., Steinetz, B.G., and Chart, J.J. (1968). Pharmacologic alteration of steroid hormone functions. Clin. Pharm. Thera. 9, 657-68I.

Gerstle, J.F. (1971). Personal communication.

Gist, D.H., and deRoos, R. (1966). Corticoids of the al1igator adrenal gland and the effects of ACTH and progesterone on their production in vitro. Gen. Comp. Endocr. $7,304-313$.

Goldman, A.S., Yakovac, W.C., and Bongiovanni, A.M. (1965). Persistent effects of a synthetic androstene derivative on activities of $3 \beta$-hydroxysteroid dehydrogenase and glucose-6-phosphate dehydrogenase in rats. Endocrinol. 77,1105 .

Gottfried, H., Huang, D.P., Lofts, B., Phillips, J.G., and Tam, W.H. (1967). In vitro production of steroids by the adrenals and testicular tissues of the cobra. Gen. Comp. Endocr. 8, 18-31. 
Holmberg, A.D., and Soler, F.I. (1942). Some notes on the adrenals: presence of a united adrenal in the marine tortoise. Contributions from the Laboratory of Anatomy, Comparative Physiology, and Pharmacodynamics, University Buenos Aires 20, 457-667.

Huang, D.P., Vinson, G.P., and Phillips, J.G. (1969). The metabolism of pregnenolone and progesterone by cobra adrenal tissue in vitro and the effect of ACTH on product yield-time curves. Gen. Comp. Endocr. 12 , $637-643$.

Jones, J.A., and Mason, J.W. (1966). A critical comparison of a chromatographic and an isotope-dialysis method of plasma 17-hydroxycorticosteroid measurement. Jour. Clin. Endocr. Metab. 26, 1001-1011.

Jørgensen, C.B. (1969). Central nervous control of adenohypophysial functions. In "Perspectives in Endocrinology." (E.J.W. Barrington and C. Barker-Jørgensen, eds.), pp. 469-54I. Academic Press, New York.

Kitay, J.I. (1968). Effects of estrogen and androgen on the adrenal cortex of the rat. In "Functions of the adrenal cortex." (K.W. McKerns, ed.), Vol. 2, pP. 775811. North Holland Publishing Co., Amsterdam.

Kleinholz, L.H. (1938). The pituitary and adrenal glands in the regulation of the melanophores of Anolis caroIinensis. Jour. Exp. Biol. 15, 477.

Licht, P., and Bradshaw, S.D. (1969). A demonstration of corticotropic activity and its distribution in the pars distalis of the reptile. Gen. Comp. Endocr. 13, 226-235.

Lofts, B., Phillips, J.G., and Tam, W.H. (1966). Seasonal changes in the testes of the cobra, Naja naja. Gen. Comp. Endocr. 6, 466-475.

Lofts, B., Phillips, J.G., and Tam, W.H. (197I). Seasonal changes in the histology of the adrenal gland of the cobra, Naja naja. Gen. Comp. Endocr. 16, 121-131.

Macchi, I.A. (1966). Regulation of reptilian and avian adrenocortical secretion: effect of ACTH on the in vitro conversion of progesterone to corticoids. Proc. 2nd Int. Congr. on Hormonal Steroids, Milan, Excerpta Medica Int. Congr. Series, 132, 1094-1103. 
Macchi, I.A., and Phillips, J.G. (1966). In vitro effect of adrenocorticotropin on corticoid secretion in the turtle, snake, and bullfrog. Gen. Comp. Endocr. 6, $170-182$.

Martoja, M., Duguy, R., and Saint Girons, H. (1961). Donnees histologiques sur les variations de le glande surrenale au cours du cycle annual, chez Vivipera aspis (L). Arch. Anat. Microsc. Morphol. Exp. 50, $233-249$.

Miller, M.R. (1955). Cyclic changes in the thyroid and interrenal glands of the viviparous lizard, Xantusia vigilis. Anat. Rec. 123, 19-31.

Murphy, B.E.P. (1967). Some studies of the protein-binding of steroids and their application to the routine micro. and ultramicro measurement of various steroids in body. fluids by competitive protein-binding radioassay. Jour. Clin. Endocr. Metab. 27, 973-990.

Nugent, C.A., arid Mayes, D.M. (1966). Plasma corticosteroids determined by use of corticosteroid-binding globulin and dextran-coated charcoal. Jour. Clin. Endocr. Metab. 26, I116-1122.

Olivereau, M. (1955). Action de la metopirone chez I'anguilie normale et hypophysectomisee, en particulier sur le systeme hypophysocorticosurrenalien. Gen. Comp. Endocr. 5, 109-128.

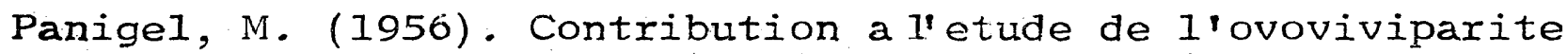
chez les Reptiles: gestation et parturition chez le lezard Zootoca vivipara. Ann. Sci. Nat. Zool. 18, 596-668.

Phillips, J.G., and Chester-Jones, I. (1957). The identity of adrenocortical secretions in lower vertebrates. Jour. Endocr. 16, iii (Abstr.).

Philitips, J.G., Chester-Jones, I., and Bellamy, D. (1962). Biosynthesis of adrenocortical hormones by adrenal glands of lizards and snakes. Jour. Endocr. 25, 233237 .

Ramirez, V.D., Abrams, R.M., and McCann, S.M. (1964). Effect of estradiol implants in the hypothalamohypophysial region of the rat on the secretion. of luteinizing hormone. Endocrinol. 75, 243-248. 
Saint Girons, H. (1963). Donnees histophysiologiques sur le cycle annuel des glandes endocrines et de leurs effecteurs chez I'orvet, Anguis fragilis (L). Arch. Anat. Microsc. Morphol. Exp. 52, $\overline{1-51 .}$

Sandor, I., Lamoureux, J., and Lanthier, A. (1964). Adrenal cortical function in reptiles: the in vitro biosynthesis of adrenal cortical steroids by adrenal slices of two common North American turtles, the slider turtle (Pseudemys scripta elegans), and the painted turtle (Chrysemys picta picta) - Steroids 4, 213-227.

Schaeffer, W.H. (1933). Hypophysectomy and thyroidectomy of the snakes Thamnophis sirtalis and Thamnophis radix. Proc. Soc. Exp. Biol. Med. 30, $\overline{1363-1365 .}$

Slaunwhite, W.R., and Sandberg, A. (1959). Transcortin: a corticosteroid-binding protein of plasma. Jour. clin. Invest. 38, 384-391.

Turner, C.D. (1966). The adrenal cortex: steroidogenic tissue. In "General Endocrinology." pp. 342-374. W.B. Saunders Co., Philadelphia.

Valle, J.R. (1945). Sobre vida da Parelheira (Phylodryas sp.) depois da adrenalectomia. Mem. Inst. Butantan, Sao Paulo 18, 237-240.

van der Molen, H.J. (1970). Electron capture detection of steroids isolated from biological samples. Annals Clin. Res. 2, 279-288.

van Kemenade, J.A.M., and van Dongen, W.J. (1965). Adrenal cortical activity in the common frog, Rana temporaria. Gen. Comp. Endocr. 5, 712.

Wagner, E.M. (1955). Effect of hypophysectomy in the turtle, Chrysemys d'orbignyi. Acta Physiol. Latinoamer. $5,219-228$.

Wright, A., and Chester-Jones, I. (1957). The adrenaI gland in lizards and snakes. Jour. Endocr. 15, 83-99. 


\section{VITA}

\section{David Reams Daugherty}

Born in Rochester, Minnesota, February 26, 1947. Graduated from John Marshall Senior High School in that city, June 1965, and from the College of William and Mary in Virginia in June 1969 with a Bachelor of Science degree. Master of Arts candidate, College of William and Mary in Virginia, with a concentration in biology, 1970 to 1971 . 